\title{
Extracellular RNAs as Biomarkers of Sporadic Amyotrophic Lateral Sclerosis and Other Neurodegenerative Diseases
}

\author{
Takashi Hosaka ${ }^{1}$, Takenari Yamashita ${ }^{2}$, Akira Tamaoka ${ }^{1}$ and Shin Kwak ${ }^{3, *}$ \\ 1 Department of Neurology, Division of Clinical Medicine, Faculty of Medicine, University of Tsukuba, \\ Tsukuba, Ibaraki 305-8575, Japan \\ 2 Department of Pathophysiology, Tokyo Medical University, Shinjuku-ku, Tokyo 160-8402, Japan \\ 3 Department of Molecular Neuropathogenesis, Tokyo Medical University, Shinjuku-ku, Tokyo 160-8402, Japan \\ * Correspondence: kwak-tky@umin.ac.jp; Tel.: +81-3-5841-3566
}

Received: 16 May 2019; Accepted: 26 June 2019; Published: 27 June 2019

\begin{abstract}
Recent progress in the research for underlying mechanisms in neurodegenerative diseases, including Alzheimer disease (AD), Parkinson disease (PD), and amyotrophic lateral sclerosis (ALS) has led to the development of potentially effective treatment, and hence increased the need for useful biomarkers that may enable early diagnosis and therapeutic monitoring. The deposition of abnormal proteins is a pathological hallmark of neurodegenerative diseases, including $\beta$-amyloid in $\mathrm{AD}, \alpha$-synuclein in PD, and the transactive response DNA/RNA binding protein of 43kDa (TDP-43) in ALS. Furthermore, progression of the disease process accompanies the spreading of abnormal proteins. Extracellular proteins and RNAs, including mRNA, micro RNA, and circular RNA, which are present as a composite of exosomes or other forms, play a role in cell-cell communication, and the role of extracellular molecules in the cell-to-cell spreading of pathological processes in neurodegenerative diseases is now in the spotlight. Therefore, extracellular proteins and RNAs are considered potential biomarkers of neurodegenerative diseases, in particular ALS, in which RNA dysregulation has been shown to be involved in the pathogenesis. Here, we review extracellular proteins and RNAs that have been scrutinized as potential biomarkers of neurodegenerative diseases, and discuss the possibility of extracellular RNAs as diagnostic and therapeutic monitoring biomarkers of sporadic ALS.
\end{abstract}

Keywords: neurodegenerative disease; amyotrophic lateral sclerosis (ALS); RNA editing; adenosine deaminase acting on RNA 2 (ADAR2); extracellular RNA; biomarker

\section{Introduction}

Neurodegenerative diseases, including Alzheimer disease (AD), Parkinson disease (PD), and amyotrophic lateral sclerosis (ALS) are characterized by the progressive loss of specific functions in the central nervous system (CNS), resulting from structural changes in selective neuronal circuits. The observation of abnormal aggregates of proteins and/or RNAs such as amyloid, tau, and the transactive response DNA/RNA binding protein of 43kDa (TDP-43) in these neuronal circuits is a pathological hallmark of these diseases [1-3]. With an advance in our understanding of disease pathogenesis, an increasing number of clinical trials of potential treatments based on plausible pathogenetic hypotheses have been conducted. Once effective treatments are a reality for neurological diseases, their success will depend upon reliable diagnostic and/or therapeutic monitoring biomarkers that enable early diagnosis and the evaluation of therapeutic efficacy.

A biomarker is characterized as an indicator of normal biological processes, pathogenic processes, or pharmacologic responses to a therapeutic intervention, which is objectively measured and evaluated [4]. Good biomarkers are useful for accurate diagnosis (diagnostic biomarker), the prediction 
of prognosis (prognostic biomarker) and response to a certain type of treatment (predictive biomarker), the determination of dosage (pharmacodynamic biomarker), and/or disease activity (disease progression biomarker) [5]. Although the definite diagnosis of neurodegenerative diseases comes from histological observation of the spinal cords and brains, biomarkers that reflect disease-specific pathological events in the CNS should be obtained in a non-invasive or low-invasive manner, including imaging and easily accessible body fluids or tissues. Liquid biopsy is a form of biopsy targeting the patient's body fluids, including serum and cerebrospinal fluid (CSF) and can be an alternative, less invasive method for conventional tissue biopsy [6]. Recently, cell-cell communication via extracellular vesicles, such as exosomes and microvesicles, is considered to be necessary in order to maintain tissue homeostasis [7]. Extracellular vesicles are secreted from several cell types in CNS tissue, including neurons, astrocytes, and microglia. Neuronal interactions via extracellular vesicles regulate neurite growth, synapse function, and neuronal regeneration [8,9]. Therefore, extracellular proteins and RNAs have been considered as promising biomarker candidates, of various types, for neurodegenerative diseases.

ALS is a fatal adult-onset motor neuron disease that is characterized by the selective degeneration of both upper and lower motor neurons. Progressive muscle weakness and atrophy result in respiratory failure, leading to death within a few years following disease onset $[10,11]$. The estimated median prevalence of ALS is 5.4 cases per 100,000 [12]. Aging is one of the strongest risk factors of ALS with a peak incidence between 60-70 years [12,13]. Although more than 50 ALS-associated genes have been identified, including superoxide dismutase 1 (SOD-1), fused in sarcoma (FUS), and chromosome 9 open reading frame 72 (C9ORF72) [14,15], only a small proportion of sporadic ALS patients (accounting for more than $90 \%$ of all ALS cases) carry any mutations in these genes. Although a large number of pathogenic hypotheses have been proposed, including protein misfolding, excitotoxicity, and oxidative stress [14], the mechanisms underlying motor neuron death in ALS remain elusive, even in familial ALS, and neither disease-modifying treatments nor reliable biomarkers of ALS are currently available [10].

In sporadic ALS, a pathological diagnostic hallmark is the disruption of the nuclear localization of TDP-43 (a nuclear protein involved in regulating RNA processing) and the deposition of cytoplasmic aggregates comprising misfolded abnormal variants of this protein in lower motor neurons [16,17]. However, no biomarkers reflecting the abnormal subcellular localization of TDP-43 in the lower motor neurons of patients are available for clinical use. The El Escorial criteria [18] and Awaji criteria [19] are the most widely used diagnostic criteria for ALS, and are based on the combination of clinical assessment and electrophysiological examination, in order to exclude patients with ALS-like symptoms and signs (such as cervical spondylosis) from clinical trials [20,21]. In agreement with reports that ALS patients do not exhibit weakness or skeletal muscle wasting until more than $30 \%$ of anterior horn neurons degenerate [22], and that patients are diagnosed with ALS after an average of one year from disease onset $[12,21,23]$, we neurologists frequently observe patients who do not meet these criteria at the initial visit, but turn out to fulfill the ALS criteria after 6-12 months in the outpatient clinic. Therefore, with the recent development of mechanism-based optimistic clinical trials, the development of diagnostic biomarkers for early phase ALS and predictive and pharmacodynamic biomarkers is crucial in order to enable the initiation of treatment, before the number of motor neurons decreases to below a level that is required to effectively control skeletal muscles.

In this review, we summarize extracellular proteins and RNAs as various types of candidate biomarkers of neurodegenerative diseases—in particular sporadic ALS—and discuss the need for the development of biomarkers based on molecular pathogenesis. Moreover, we also discuss the possibility of extracellular RNAs as biomarker candidates based on excitotoxicity, which is a plausible pathogenesis of sporadic ALS.

\section{Extracellular RNAs}

RNAs, including mRNA, micro RNA (miRNA) and circular RNA (circRNA), are secreted from cells in forms such as exosomes, microvesicles, and RNA binding proteins (RBP), and are referred to as extracellular RNAs (Figure 1) [24]. These extracellular RNAs may represent the pathological 
process in the host cells and remain in body fluids such as blood, urine, and CSF [25], suggesting that these RNAs are potentially good disease biomarkers $[24,26,27]$. Recently, evidence suggesting that RNAs and RNA-binding proteins play important roles in the pathogenesis of sporadic ALS, has been increasing $[15,28]$. In accordance with a recent focus on RNA-mediated cell-cell communication, extracellular RNAs are regarded as hopeful new biomarker candidates of neurodegenerative diseases, including ALS.

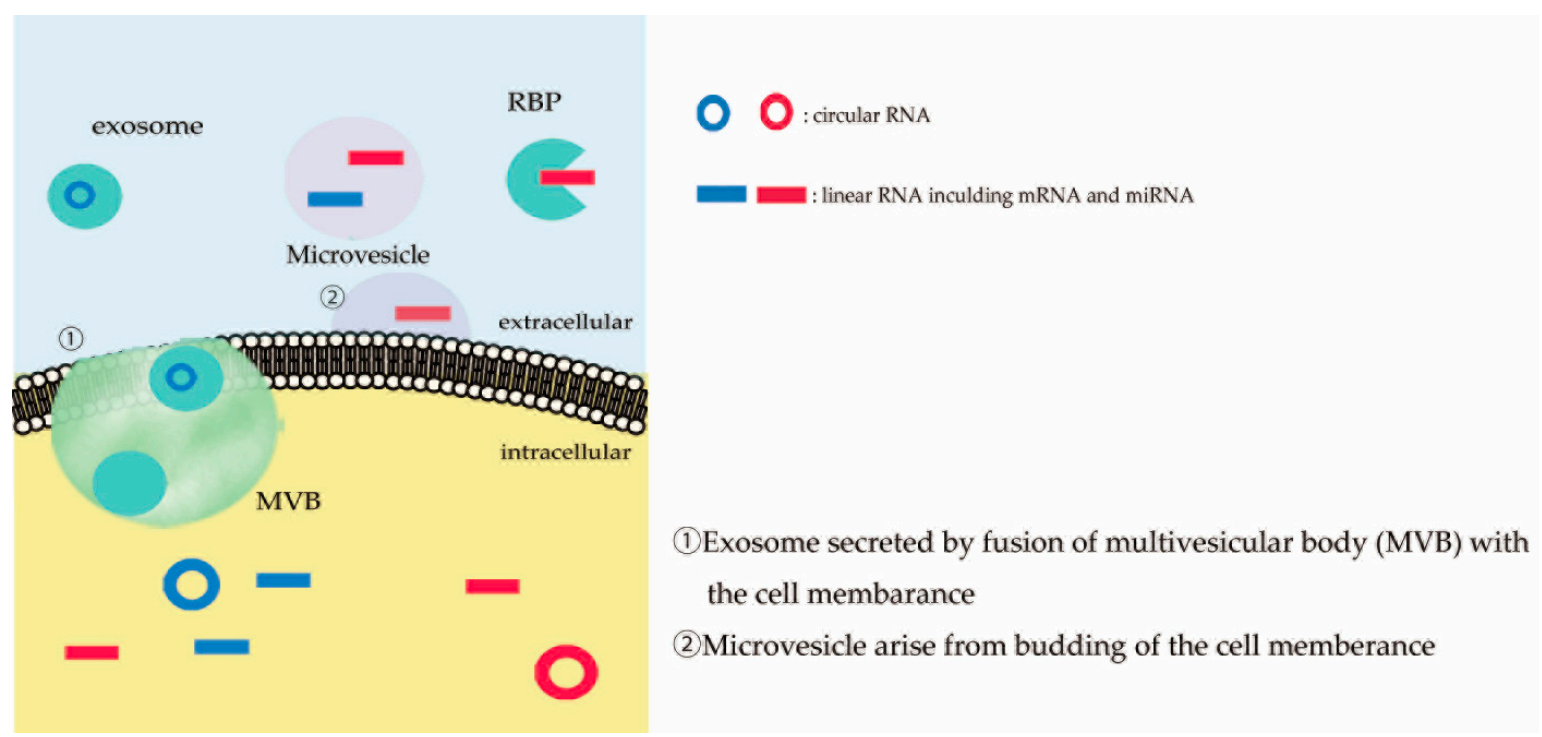

Figure 1. Extracellular RNAs. RNAs are found extracellularly, as extracellular vesicles or RNA binding proteins (RBP)-RNA complexes. Circles and lines indicate circular RNAs and linear RNAs, respectively.

Cells secrete cellular composite molecules into extracellular space as a package surrounded by membranes called vesicles, which are classified into four types mainly according to their size and biogenesis; exosomes, microvesicles, apoptotic bodies, and RBPs [24]. Exosomes, measuring 40-100 $\mathrm{nm}$ in diameter, arise from intraluminal vesicles in multivesicular bodies (MVBs) and are secreted by the fusion of MVBs with the cell membrane [7,29]. Although exosome secretion was initially considered as a way of eliminating unnecessary compounds from cells, secreted molecules are now considered intracellular communication mediators, since cell-cell communications through exosomes has been reported [30]. Microvesicles measuring 100-1000 nm in diameter arise from the budding of the cell membrane, and have also been considered to play a role in cell-cell communication due to the transport of transmembrane proteins between microglia and astrocytes, through microvesicles, activating membrane proteins [31]. Apoptotic bodies, measuring 500-2000 nm in diameter, are released through blebbing of the cell membrane of apoptotic cells, and include nucleotides and cell organelles [32]. RBPs, including high-density lipoproteins, argonaute 2, and nucleophosmin 1 , also bind extracellular RNAs [33-35]. These extracellular vesicles and RBPs protect extracellular RNAs from digestion by ribonucleases, enabling RNAs to remain in the extracellular space [24]. Therefore, extracellular RNAs are considered to be a candidate biomarker of human diseases, including neurodegenerative diseases.

The secretion of extracellular RNAs is stimulated in some adverse conditions, including hypoxia and events activating immune responses [36], and the levels of some extracellular RNAs are changed with aging [37]. It was reported that miRNAs in exosomes, and mRNA and some circRNAs in other forms, reflect their intracellular expression profiles [38], suggesting that the analysis of extracellular RNAs may indicate the health level of cells and hence, extracellular RNAs in appropriate forms can be potential biomarkers of human diseases.

MiRNAs are short non-coding RNAs (21-24 nucleotides), and are produced by two RNase III proteins, Drosha and Dicer [39]. They regulate gene expression by binding to the $3^{\prime}$-untranslated regions of mRNA, and play important roles in brain development [1] and various cellular processes, 
including apoptosis and response to immune stimuli and stress [40]. The adenosine-to-inosine (A-to-I) conversion of RNA (RNA editing) in primary miRNA influences miRNA biogenesis and function by switching target mRNAs [41]. Changes in the expression levels of miRNAs have been detected in neurodegenerative diseases such as $\mathrm{AD}, \mathrm{PD}$, and ALS, and miRNAs regulate protein levels involved in the pathogenesis of neurodegenerative diseases, through the regulation of their host gene expression [42], suggesting that miRNAs are candidate biomarkers of neurodegenerative diseases, including ALS.

CircRNAs are produced by back-splicing, which covalently links the $3^{\prime}$ end of an exon to the $5^{\prime}$ end of an upstream exon [43], and are also detected in extracellular fluid [44]. The complementary sequence across flanking introns-and nucleotide changes due to RNA editing by adenosine deaminase acting on RNA 1 (ADAR1) in the flanking introns-influence the biogenesis of circRNA $[45,46]$. Intriguingly, FUS, a mutation that is a causative for familial ALS, has also been shown to be involved in the biogenesis of circRNA [47]. The functions of circRNAs are largely unknown, except for that of regulating gene expression, the sponging of miRNA, RNA splicing, and cell cycle regulation, by interacting with proteins [43]. CircRNAs were widely expressed throughout the organs, especially in the CNS, and the extracellular levels of some circRNAs are more than 10-fold higher than intracellular levels, suggesting that circRNAs are actively secreted from cells $[45,48,49]$. The expression levels of circRNAs are increased with cell differentiation in SH-SY5Y cells and with aging in the adult mouse brain $[50,51]$. The characteristic circular structure protects circRNAs from digestion by ribonucleases and provides a longer half-life compared with linear RNAs [48]. Although no circRNAs have been established as biomarkers of neurodegenerative diseases, a long half-life and an abundance in the CNS of the aged, are advantages that allow circRNAs to be candidate biomarkers in aging associated neurodegenerative diseases.

\section{Liquid Biopsy in Neurodegenerative Diseases}

Increasing numbers of clinical trials of candidate drugs that target potential causative molecules have been conducted in $\mathrm{AD}$ and $\mathrm{PD}$, which are the first and second most prevalent neurodegenerative diseases, respectively $[52,53]$. Currently, molecular imaging such as amyloid positron emission tomography (PET), dopamine transporter single-photon emission computed tomography (DAT-SPECT), and ${ }^{123}$ I meta-iodobenzylguanidine (MIBG) myocardial scintigraphy are used as diagnostic biomarkers in clinical trials. However, high costs and a limited number of facilities where molecular imaging is available necessitate the development of more feasible biomarkers. As the examination of body fluids is widely performed, extracellular proteins and RNAs in the body fluids can be potential candidates for biomarkers, provided that proteins or RNAs represent the pathological neurodegenerative processes. In this section, we discuss the candidate diagnostic biomarkers of AD and PD investigated to date, which can be obtained by liquid biopsy.

\subsection{Alzheimer Disease}

$\mathrm{AD}$ is characterized by progressive memory loss, the neuropathological presence of neuronal hyperphosphorylated tau, and widespread A $\beta$ deposition in the cortices [52]. Since A $\beta$ peptides secreted from cells in exosomes accumulate in amyloid plaques [54], cell-cell communication via extracellular vesicles is considered to be involved in the pathogenesis of AD.

The 42 amino acid form of $A \beta$ (A $\beta 42)$, total tau (T-tau), and phosphorylated tau (P-tau) have been identified in patients' CSF [55]. In the CSF of AD patients, A $\beta 42$ levels are significantly decreased compared with normal control subjects. Patients also show pathological cortical amyloid changes, and T-tau and P-tau levels are significantly increased, which is in parallel with the accumulation of neocortical neurofibrillary tangles [56]. Since the changes are highly sensitive and specific (80-90\%) to $\mathrm{AD}$ [57], these three core biomarkers in the CSF are disease-specific diagnostic biomarkers. However, in the plasma of $\mathrm{AD}$ patients, changes in $\mathrm{A} \beta 42$ levels are opposite to the levels in the 
CSF and significantly increased $[58,59]$, whereas T-tau and P-tau levels are significantly increased in concordance with the levels in CSF [60,61].

Other promising diagnostic biomarker candidates in the CSF are neurofilament light chain (NEFL), neuron-specific enolase (NSE), visinin-like protein 1 (VILIP-1), heart fatty acid binding protein (H-FABP), and chitinase-3-like protein 1 (YKL-40) [55]. NEFL is a component of the axonal cytoskeleton and is involved in the maintenance of axonal structure and function [62]. Levels in the CSF, serum, and plasma are significantly increased in AD patients [63-65] and in multiple sclerosis (MS) and PD as well [66]. NSE is a neuronal glycolytic enzyme that is localized in the cytoplasm, and is involved in neuronal differentiation [67]. NSE levels in the CSF are significantly increased in some [68-70], but not in most AD patients [71-73], or patients with stroke, cerebral hemorrhage, or brain trauma as well [70]. VILIP-1, a neuronal calcium sensor protein involved in calcium-mediated neurotoxicity, and H-FABP, a fatty acid binding protein involved in the uptake, transport, and metabolism of fatty acid, are potential markers of brain injury [72,74], and their levels in CSF are significantly increased [72,74-78]. YKL-40 is a marker of neuroinflammation, and its levels in CSF are significantly increased in some [78-80] - but not all-AD patients [81] and in MS patients as well [82]. Although currently none of them has been established as a reliable biomarker, recent advances in the technology enabling the detection of tiny and potential disease-specific changes in the molecules in the patient's body fluids [59] will enable the development of these in the future.

RNAs, especially non-coding RNAs, including miRNA, long non-coding RNA (lncRNA), and circRNA, play roles in AD pathogenesis by regulating the disease onset [40], rendering extracellular RNAs candidates biomarkers of $\mathrm{AD}$, such as extracellular proteins. Multiple lines of study report significant differences in the levels of miRNAs in the CSF or serum between patients with AD and control subjects [83-87]; the upregulation of let-7d (in plasma and whole blood), let-7f (in serum), let-7g (plasm), miR-106a (in serum), miR-106b (in serum), miR-142 (in whole blood), miR-15b (in plasma), miR-191 (in plasma), miR-3065 (in serum), miR-34a (in plasma), miR-483 (in plasma), miR-9 (in serum), miR-127 (in serum), and miR-30c (in CSF) and downregulation of let-7d (in serum), let-7g (in serum), miR-106a (in whole blood), miR-106b (in whole blood), miR-107 (in plasma and whole blood), miR-125b (in serum and plasma), miR-146a (in serum and plasma), miR-15b (in serum), miR-181c (in serum), miR-191 (in serum), miR-26a (in serum), miR-29b (in plasma and peripheral blood mononuclear cells (PBMCs)), miR-3065 (in plasma), miR-342 (in serum and plasma), miR-483 (in serum), miR-9 (in whole blood and CSF), miR-127 (in CSF), miR-184 (in CSF), and miR-195 (in CSF) have been reported. However, inconsistency among results has failed to establish diagnostic biomarkers of AD.

\subsection{Parkinson Disease}

Parkinson disease is characterized by the death of dopaminergic neurons in the substantia nigra, which leads to movement dysfunction, including resting tremor, bradykinesia, muscular rigidity, and postural and gait impairment [53]. Since motor symptoms commence at the time when as many as $50 \%$ of dopaminergic neurons have already been lost, and clinical manifestations in early stages are sometimes difficult to distinguish PD from other diseases with parkinsonism, such as progressive supranuclear palsy (PSP) and multiple system atrophy (MSA) [88,89], the development of early diagnostic biomarkers is required.

One of the most extensively investigated biomarker candidates is $\alpha$-synuclein: a composite molecule of the cytoplasmic inclusion bodies in the dopaminergic nigral neurons, which are called Lewy bodies, and are the pathological hallmark of PD [53]. Levels of total $\alpha$-synuclein in CSF are significantly decreased [90-94], whereas those of oligomeric and phosphorylated forms are significantly increased in the CSF and plasma of PD patients compared with non-PD patients and control subjects [95-97], suggesting that the change of oligomer/total- $\alpha$-synuclein concentrations may be a useful biomarker for the early diagnosis of PD [96]. Although a significant increase in the levels of NEFL in CSF, plasma, and sera from PD patients can be a potential biomarker 
distinguishing from control subjects, a large overlap in the values between PD and disease control patients, including PSP and MSA $[94,98,99]$, suggests that an increase of NEFL cannot be a disease biomarker distinguishing PD from other diseases with parkinsonism. [98,100,101]. None of the candidate biomarker proteins, including parkinsonism-associated deglycase (DJ-1), brain-derived neurotrophic factor (BDNF), and glutathione $[102,103]$ have been established as diagnostic biomarkers of PD.

RNAs have also been investigated as possible biomarkers of PD. MiRNAs have been investigated as possible diagnostic biomarker candidates in PD [104]; the upregulation of miR-153 (in CSF), miR-205 (in CSF), miR-30a (in whole blood), miR-26a (in whole blood), miR-16-2 (in whole blood), and miR-29a (in PBMCs) and the downregulation of miR-1 (in CSF and whole blood), miR-29a (in CSF and serum), miR-22 (in whole blood), miR-124 (in serum), miR-221 (in serum), and miR-126 (in PBMCs) [105] have been reported, but with a lack of consistency among the reports.

\section{Liquid Biopsy in Sporadic ALS}

Comprehensive analysis of the ALS patient CSF proteome suggested that changes in extracellular proteins may be candidates for various types of biomarkers [106-109]. Some of these extracellular proteins, including TDP-43, NEFL, neurofilament heavy chain (NEFH), and extracellular domain of the common neurotrophin receptor p75 $\left(\mathrm{p} 75^{\mathrm{ECD}}\right)$ are summarized in Table 1.

\subsection{Diagnostic Biomarkers}

TDP-43 pathology or the mislocalization of TDP-43 from the nucleus to the abnormal inclusion in the cytoplasm is the pathological diagnostic hallmark of sporadic ALS, indicating that extracellular molecules that reflect TDP-43 mislocalization would be good diagnostic biomarkers. The TDP-43 concentration in the CSF of ALS patients is significantly higher than that of normal control subjects, Guillain-Barre syndrome, MS patients, and PD patients [110-114], whereas exosomal TDP-43 levels in CSF were not different between the normal control subjects and ALS patients [114].

Neurofilaments, including NEFL and NEFH, have been investigated as possible biomarkers of sporadic ALS [115]. Mutations in the NEFL gene cause Charcot-Marie-Tooth disease type 2 (CMT2) and mutations of NEFH and neurofilament hyperphosphorylations are associated with ALS, AD, and PD [116]. Several studies indicated that NEFL and phosphorylated NEFH (pNEFH) levels were significantly increased in the CSF and serum from ALS patients compared with normal control subjects and disease control patients [117-124], and the extent of the increase in ALS was highest among neurodegenerative diseases, including AD and PD [119,124], and as high as in chronic inflammatory demyelinating polyneuropathy (CIDP) $[119,123,124]$.

Activation of the neurotrophin receptor $p 75$ in response to the nerve growth factor released by activated astrocytes plays a role in developmental motor neuron death and neuronal injury [125]. The levels of urinary $\mathrm{p} 75^{\mathrm{ECD}}$ are increased in ALS patients compared with normal control subjects and patients with other neurological diseases such as PD and MS [126-128]. The levels of neurotrophin receptor p75 in tissues are upregulated also in $\mathrm{AD}$, ischemic stroke, and seizure, suggesting a response to non-specific neuronal injury and cell stress [129]. 
Table 1. Proteins considered as biomarker candidates of sporadic amyotrophic lateral sclerosis (ALS). ALSFS-R: ALS functional rating scale-revised, CSF: cerebrospinal fluid, TDP-43: transactive response DNA/RNA binding protein of 43kDa, FTLD: frontotemporal lobar degeneration.

\begin{tabular}{|c|c|c|c|c|c|c|c|}
\hline Proteins & $\begin{array}{l}\text { Changes } \\
\text { in Levels }\end{array}$ & $\begin{array}{l}\text { Kinds of } \\
\text { Body }\end{array}$ & Biomarkers & \multicolumn{2}{|c|}{ Patients (Origin and Number) } & Disease Specificity & Reference \\
\hline \multirow{8}{*}{ TDP-43 } & \multirow{8}{*}{ Increase } & \multirow{8}{*}{ CSF } & \multirow{5}{*}{ Diagnostic } & Germany & $\begin{array}{c}15 \text { sporadic ALS } \\
12 \text { FTLD } \\
9 \text { ALS + FTLD } \\
13 \text { disease controls }\end{array}$ & \multirow{5}{*}{$\begin{array}{c}\text { Low (not } \\
\text { disease-specific) }\end{array}$} & [110] \\
\hline & & & & Japanese & $\begin{array}{l}30 \text { sporadic ALS } \\
29 \text { disease controls }\end{array}$ & & [111] \\
\hline & & & & Japanese & $\begin{array}{c}27 \text { sporadic ALS } \\
50 \text { disease controls }\end{array}$ & & [112] \\
\hline & & & & Japanese & $\begin{array}{c}13 \text { sporadic ALS } \\
7 \text { GBS }\end{array}$ & & [113] \\
\hline & & & & Germany & $\begin{array}{c}9 \text { sporadic ALS } \\
4 \text { FTLD } \\
8 \text { control subjects }\end{array}$ & & [114] \\
\hline & & & & Japanese & $\begin{array}{l}29 \text { disease controls } \\
27 \text { sporadic ALS }\end{array}$ & High (correlation & [111] \\
\hline & & & Prognostic & Japanese & $\begin{array}{c}27 \text { sporadic ALS } \\
50 \text { disease controls }\end{array}$ & $\begin{array}{l}\text { With survival time } \\
\text { and disease } \\
\text { duration) }\end{array}$ & [112] \\
\hline & & & & Japanese & $\begin{array}{c}13 \text { sporadic ALS } \\
7 \text { GBS }\end{array}$ & & [113] \\
\hline & & & & Germany & $\begin{array}{c}67 \text { sporadic ALS } \\
2 \text { familial ALS } \\
33 \text { control subjects }\end{array}$ & & [117] \\
\hline & & & & American & $\begin{array}{l}20 \text { sporadic ALS } \\
20 \text { control subjects }\end{array}$ & & [118] \\
\hline & & & & Germany & $\begin{array}{l}222 \text { sporadic ALS } \\
20 \text { familial ALS } \\
199 \text { disease controls }\end{array}$ & & [119] \\
\hline & & & Diagnostic & Germany & $\begin{array}{l}194 \text { sporadic ALS } \\
26 \text { familial ALS } \\
316 \text { disease controls }\end{array}$ & $\begin{array}{c}\text { Low (not } \\
\text { disease-specific) }\end{array}$ & [120] \\
\hline & & & & European & $\begin{array}{l}176 \text { sporadic ALS } \\
63 \text { disease controls }\end{array}$ & & [121] \\
\hline & & & & Chinese & $\begin{array}{c}53 \text { sporadic ALS } \\
32 \text { disease controls }\end{array}$ & & [122] \\
\hline & & CSF & & American & $\begin{array}{l}134 \text { sporadic ALS } \\
15 \text { familial ALS } \\
101 \text { disease controls }\end{array}$ & & [123] \\
\hline & & & & Germany & $\begin{array}{l}124 \text { sporadic ALS } \\
109 \text { disease controls } \\
50 \text { control subjects }\end{array}$ & & [124] \\
\hline & & & \multirow{5}{*}{ Prognostic } & Germany & $\begin{array}{l}67 \text { sporadic ALS } \\
2 \text { familial ALS } \\
33 \text { control subjects }\end{array}$ & \multirow{5}{*}{$\begin{array}{l}\text { High (correlation } \\
\text { with survival time } \\
\text { and disease } \\
\text { duration) }\end{array}$} & [117] \\
\hline \multirow{4}{*}{$\begin{array}{l}\text { Neurofilament } \\
\text { (NEFL or } \\
\text { pNEFH) }\end{array}$} & \multirow{4}{*}{ Increase } & & & Germany & $\begin{array}{l}222 \text { sporadic ALS } \\
20 \text { familial ALS } \\
199 \text { disease controls }\end{array}$ & & [119] \\
\hline & & & & Germany & $\begin{array}{l}194 \text { sporadic ALS } \\
26 \text { familial ALS } \\
316 \text { disease controls }\end{array}$ & & [120] \\
\hline & & & & European & $\begin{array}{l}176 \text { sporadic ALS } \\
63 \text { disease controls }\end{array}$ & & [121] \\
\hline & & & & Chinese & $\begin{array}{l}53 \text { sporadic ALS } \\
32 \text { disease controls }\end{array}$ & & [122] \\
\hline
\end{tabular}


Table 1. Cont.

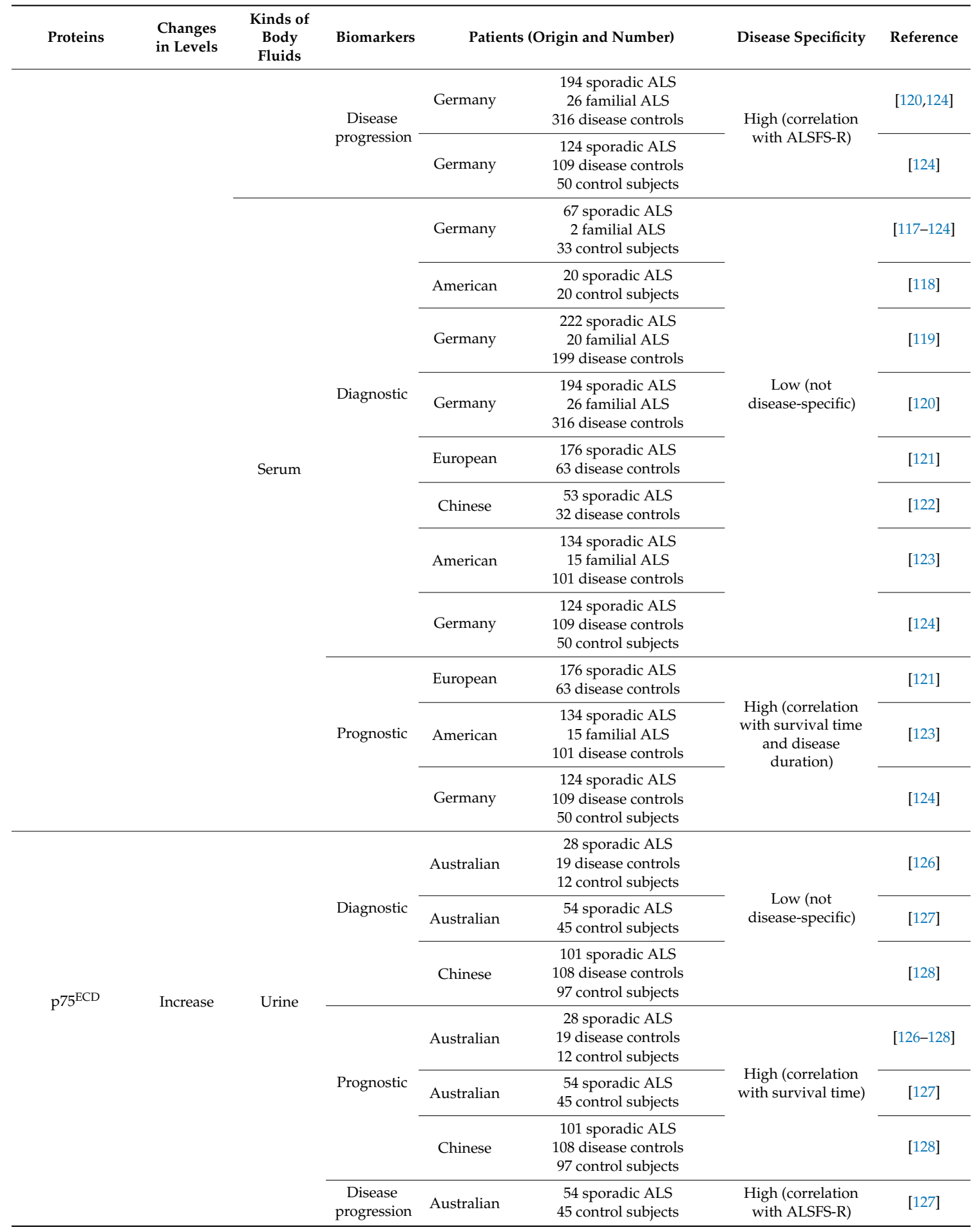

Therefore, changes in TDP-43, NEFL, pNEFH, and urinary $\mathrm{p} 75^{\mathrm{ECD}}$ levels in body fluids reflect adverse cellular events that are not specifically associated with ALS pathogenesis, suggesting that they may not become disease-specific diagnostic biomarkers.

\subsection{Other Types of Biomarkers}

Changes in TDP-43, NEFL, pNEFH, and urinary $\mathrm{p} 75^{\mathrm{ECD}}$ levels are potential prognostic and/or disease progression biomarkers. 
Reduced TDP-43 levels ( $\leq 27.9 \mathrm{ng} / \mathrm{mL})$ in CSF are associated with shorter survival times [112], while higher NEFL and pNEFH levels in the CSF and serum are associated with more rapid progression speed and poorer prognosis $[117,120,123,124]$, and higher urinary $\mathrm{p} 75^{\mathrm{ECD}}$ levels are associated with more rapid progression [126-128]. Urinary $\mathrm{p} 75^{\mathrm{ECD}}$ levels increase linearly with disease progression from the time of diagnosis and are correlated with clinical disease parameters, ALS functional rating scale-revised (ALSFS-R) [120,127]. Changes in NEFL and pNEFH levels in CSF, but not in serum, from patients with fast and immediate disease progression speed increased with disease duration and ALSFS-R $[120,124]$, suggesting that these changes may be disease progression biomarkers.

These extracellular proteins may become potential biomarkers for prognosis and/or disease progression of sporadic ALS, when proven by additional comprehensive studies in the future.

\section{RNAs as Biomarker Candidates of Sporadic ALS}

Many of the so-far identified ALS-linked genes are involved in RNA processing [28], but only a small proportion of sporadic ALS patients carry any of these mutated genes, including C9ORF72, FUS, TDP-43, and ataxin 2 (ATXN2). Abnormal GGGGCC hexanucleotide repeat expansion in the C9ORF72, which is the most common gene associated with familial and sporadic ALS in Western countries, alters the RNA binding activity of the translated C9ORF72 protein through the formation of RNA foci $[130,131]$. Mutations in the SOD-1 gene, the common genetic cause among familial ALS patients and identified in 2-7\% of sporadic ALS patients, affect the expression levels of vascular endothelial growth factor-A (VEGFA) mRNA and NEFL mRNA $[15,28]$. FUS and TDP-43 are involved in the transcription and splicing of RNAs, and mutations in the encoding genes are identified in a few percentage points of familial ALS and in approximately 1\% of sporadic ALS [15]. Additionally, other genes involved in RNA regulation, including ATXN2 and matrin 3 (MATR3), are found to be causative genes of familial ALS, and are also identified in sporadic ALS [131]. Therefore, RNA dysregulation mechanisms are the plausible pathogenesis of sporadic ALS, as well as familial ALS. As the role of extracellular RNAs in the cell-cell communication has recently been highlighted, extracellular RNAs are hopeful new biomarker candidates of sporadic ALS (Tables 2 and 3).

\subsection{Diagnostic Biomarkers}

Comprehensive studies on the expression levels of mRNA in whole blood and PBMCs reported that the expression levels of as many as 2943 mRNAs [132] and 2300 mRNAs in whole blood [133], and those of 87 mRNAs in PBMCs were significantly different among ALS patients, the normal control subjects, and the disease control patients [134]. However, the different RNAs were not the same among these reports.

Expression levels of the below-mentioned 13 mRNAs that are potentially involved in the pathogenesis of ALS, have been compared between ALS and normal control subjects and disease control patients by using quantitative polymerase chain reaction (qPCR) (Table 2) [135-138].

VEGFA was suggested to play a role in neuroprotection via activating VEGF receptor 2 and neuropilin-1 in various neurodegenerative diseases, including ALS [139] and mice with a homozygous deletion in the hypoxia response element of the VEGFA promoter exhibited classical ALS-like symptoms [140]. C-C motif Chemokine ligand 2 (CCL2) was also suggested to play a role in neuroprotection from excitotoxicity, by reducing glutamate release from the presynapses and/or facilitating the re-uptake of glutamate in the astrocytes at synapses [141]. Kinesin family member 5C (KIF5C) and dynactin subunit 1 (DCTN1) are motor proteins of axonal flow, and their defects have been shown to be associated with motor neuron death [142,143]. Studies using qPCR [135,136], but not those using RNA sequencing (RNAseq), reported a significant increase in the expression levels of all these four mRNAs (VEGFA mRNA, CCL2 mRNA, KIF5C mRNA, and DCTN1 mRNA) in the PBMCs from ALS patients.

Neurotrophic factors, including BDNF, neurotrophic receptor tyrosine kinase 2 (NTRK2), phosphatidylinositol-4,5-bisphosphate 3-kinase catalytic subunit alpha (PIK3CA), AKT serine/threonine 
kinase 1 (AKT1), glycogen synthase kinase $3 \beta$ (GSK3 $\beta$ ), nuclear factor $\kappa B(\mathrm{NF} \kappa \mathrm{B})$, and Fas ligand (FASLG), play roles in the development and synaptic plasticity of the nervous system, suggesting pathogenic roles in neurological diseases [144]. Indeed, studies using qPCR demonstrated an increase of the expression levels of mRNAs of all these neurotrophic factors in peripheral blood leukocytes (PBL) and four of them (BDNF mRNA, PIK3CA mRNA, AKT1 mRNA, and NFKB mRNA) in whole blood from ALS patients [138].

Cytoplasmic fragile $X$ mental retardation interacting protein 2 (CYFIP2) and retinoblastoma binding protein 9 (RBBP9) are apoptosis regulatory proteins. CYFIP2 evokes p53-induced apoptosis [145], and RBBP9 competes with RB binding to E2F transcription factor 1 (E2F-1) and evokes E2F-1-induced apoptosis [146]. Expression levels of CYFIP2, mRNA, and RBBP9 mRNA were significantly increased in PBL and whole blood from ALS patients [137].

All of the above-mentioned proteins have been proposed to play important roles in other neurodegenerative diseases as well [136,147-149], suggesting that the changes in expression levels of these 13 mRNAs would reflect relatively non-selective pathological processes in the CNS. Due to the lack of disease specificity in ALS, these mRNAs cannot be disease-specific diagnostic biomarkers.

Similar to mRNA, miRNAs play important roles in motor neuron homeostasis [150], and hence have been investigated as potential diagnostic biomarker candidates of sporadic ALS [27]. Due to their stability in the extracellular space, miRNAs are considered to be better biomarker candidates than mRNAs. Although a number of studies have reported the differences in the expression levels of miRNAs between control and ALS patients in body fluids [27], only a few of them reported differences in the expression levels of miRNAs that were associated with motor neuron homeostasis (Table 3) [151-160].

MiR-9 plays an important role in the regulation of axonal development via suppressing microtubule-associated protein 1B (MAP1B) [161], in the differentiation of spinal motor neurons via repressing the transcription factors onecut (OC1) and forkhead box P1 (FoxP1) [162,163], in cytoskeletal integrity via regulating the expression of NEFH mRNA [164], and in neuron regeneration via regulating the expression of monocyte chemotactic protein-1-induced protein-1 (MCPIP1) [165]. Studies have shown that the expression levels of miR-9 were significantly increased in the CSF, plasma, and PBL from ALS patients [151-153].

MiR-124 mediates the development of spinal motor neurons by silencing repressor element-1 silencing transcription factor (REST) [166], and the regeneration of neurons by upregulating crucial genes. MiR-124 also serves as an indirect regulator of expression of excitatory amino acid transporter 2 (EAAT2) mRNA [167]. The expression levels of miR-124 have been shown to be significantly increased in the CSF of ALS patients [152].

MiR-146a is a critical regulator of expression of NEFL mRNA that is involved in the maintenance of cytoskeletons [168]. Studies have shown that the expression levels of miR-146a were significantly decreased in serum, but had inconsistency in the CSF of ALS patients [152,154,155].

MiR-128 reduces Ras homolog family member A (RhoA) activity by silencing Rho guanine nucleotide exchange factor (PDZ-RhoGEF), leading to neurite growth promotion [169]. The expression level of miR-128 is significantly decreased in the whole blood from ALS patients [156].

MiR-183 is a key regulator of neurite growth by suppressing the expression of mammalian target of rapamycin (mTOR) mRNA [170], and its expression levels have been shown to be significantly decreased in whole blood and PBL from ALS patients [156,157].

MiR-206 is a skeletal muscle-specific miRNA that plays a role in the maintenance and regeneration of the neuromuscular junction [171]. Also, the expression levels of miR-206 were significantly increased in serum and PBL from ALS patients [151,153,158,159].

MiR-338-3p is involved in the apoptosis of mature neuron and the neurodegeneration of oligodendrocytes due to modulating apoptosis-associated tyrosine kinase (AATK) mRNA levels in neurons. In addition, miR-338-3p suppresses the expression levels of SLC1A2 mRNA, suggesting a role in glutamate clearance [172]. Compared with control subjects, the expression levels of miR-338-3p 
were significantly increased in the serum, PBL, and CSF of ALS patients, and in PBL from other neurodegenerative disease such as AD and PD, as well [172,173].

MiR-133b plays an important role in the differentiation and degeneration of midbrain dopaminergic neurons and promotes neuritis outgrowth $[174,175]$. The expression levels of miR-133b were significantly increased in the serum and plasma of ALS patients [176].

Table 2. mRNAs related to the pathogenesis of ALS and considered as biomarker candidates of sporadic ALS. PBMCs: plasma and peripheral blood mononuclear cells.

\begin{tabular}{|c|c|c|c|c|c|c|}
\hline mRNA & $\begin{array}{l}\text { Changes in } \\
\text { Levels }\end{array}$ & $\begin{array}{c}\text { Kinds of } \\
\text { Body Fluids }\end{array}$ & \multicolumn{2}{|c|}{ Patients (Origin and Number) } & Disease Specificity & Reference \\
\hline \multicolumn{7}{|c|}{ Diagnostic biomarkers } \\
\hline $\begin{array}{l}\text { VEGFA } \\
\text { mRNA }\end{array}$ & Increase & PBMCs & Indian & $\begin{array}{c}50 \text { sporadic ALS } \\
50 \text { control subjects }\end{array}$ & Low (not disease-specific) & [135] \\
\hline $\begin{array}{l}\text { CCL2 } \\
\text { mRNA }\end{array}$ & Increase & PBMCs & Indian & $\begin{array}{c}50 \text { sporadic ALS } \\
50 \text { control subjects }\end{array}$ & Low (not disease-specific) & [135] \\
\hline $\begin{array}{l}\text { DCTN1 } \\
\text { mRNA }\end{array}$ & Increase & PBMCs & Polish & $\begin{array}{c}74 \text { sporadic ALS } \\
28 \text { disease controls } \\
65 \text { control subjects }\end{array}$ & Low (not disease-specific) & [136] \\
\hline $\begin{array}{l}\text { BDNF } \\
\text { mRNA }\end{array}$ & Decrease & PBL & Dutch & $\begin{array}{l}50 \text { sporadic ALS } \\
50 \text { disease control } \\
50 \text { control subjects }\end{array}$ & $\begin{array}{l}\text { Low (inconsistent results, not } \\
\text { disease-specific) }\end{array}$ & [132] \\
\hline $\begin{array}{l}\text { NTRK2 } \\
\text { mRNA }\end{array}$ & Decrease & PBL & Indian & $\begin{array}{c}64 \text { sporadic ALS } \\
122 \text { disease controls } \\
120 \text { control subjects }\end{array}$ & Low (not disease-specific) & [138] \\
\hline \multirow{2}{*}{$\begin{array}{l}\text { PIK3CA } \\
\text { mRNA }\end{array}$} & Decrease & PBL & Dutch & $\begin{array}{c}50 \text { sporadic ALS } \\
50 \text { disease control } \\
50 \text { control subjects }\end{array}$ & \multirow{2}{*}{$\begin{array}{l}\text { Low (inconsistent results, not } \\
\text { disease-specific) }\end{array}$} & [132] \\
\hline & Increase & Whole blood & Indian & $\begin{array}{c}64 \text { sporadic ALS } \\
122 \text { disease controls } \\
120 \text { control subjects }\end{array}$ & & [138] \\
\hline $\begin{array}{l}\text { AKT1 } \\
\text { mRNA }\end{array}$ & Decrease & PBL & Dutch & $\begin{array}{c}50 \text { sporadic ALS } \\
50 \text { disease control } \\
50 \text { control subjects }\end{array}$ & $\begin{array}{l}\text { Low (inconsistent results, not } \\
\text { disease-specific) }\end{array}$ & [132] \\
\hline \multirow{2}{*}{$\begin{array}{l}\text { NFKB } \\
\text { mRNA }\end{array}$} & Decrease & PBL & American & $\begin{array}{c}123 \text { sporadic ALS } \\
123 \text { control subjects }\end{array}$ & \multirow{2}{*}{$\begin{array}{l}\text { Low (inconsistent results, not } \\
\text { disease-specific) }\end{array}$} & [133] \\
\hline & Increase & Whole blood & Indian & $\begin{array}{c}64 \text { sporadic ALS } \\
122 \text { disease controls } \\
120 \text { control subjects }\end{array}$ & & {$[138]$} \\
\hline $\begin{array}{l}\text { FASLG } \\
\text { mRNA }\end{array}$ & Increase & PBL & Indian & $\begin{array}{c}64 \text { sporadic ALS } \\
122 \text { disease controls } \\
120 \text { control subjects }\end{array}$ & Low (not disease-specific) & [138] \\
\hline
\end{tabular}


Table 2. Cont.

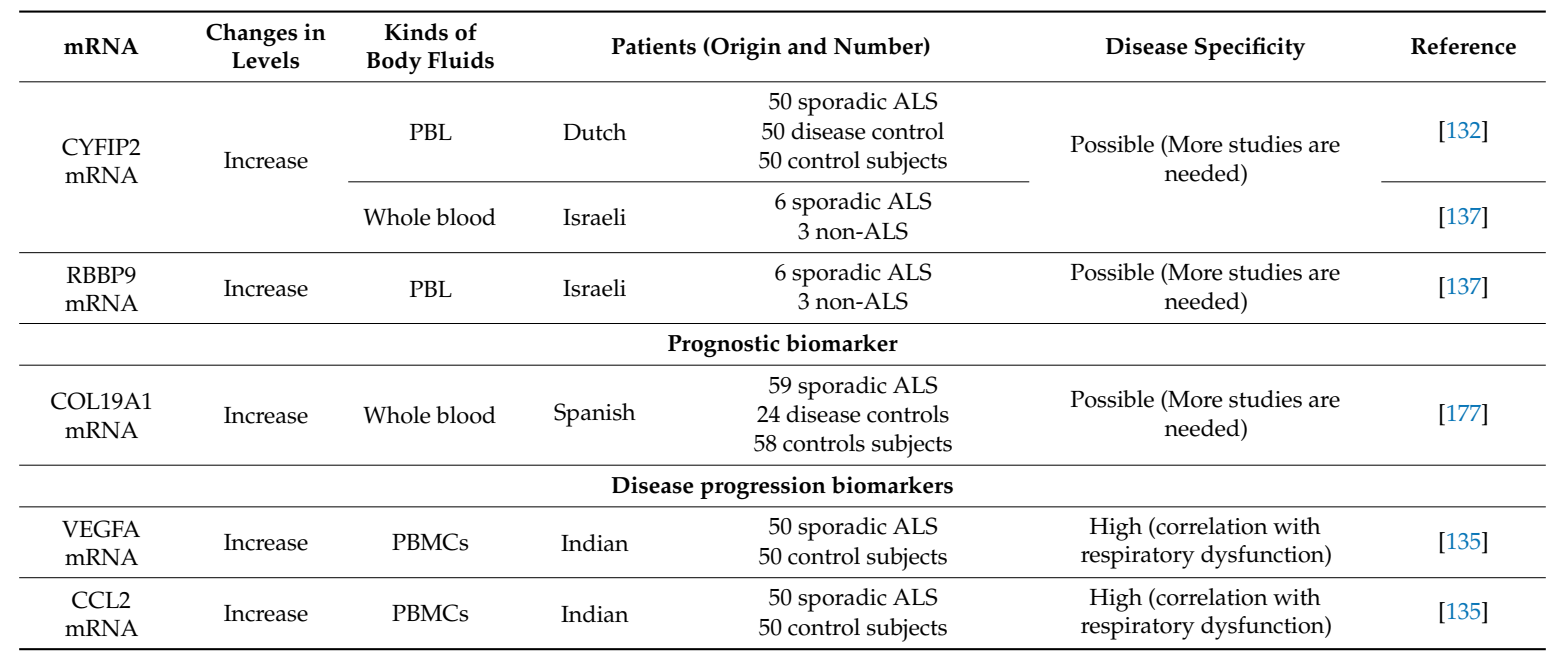

As similar changes have been detected in the body fluids from patients with neurodegenerative diseases other than ALS, and because some studies demonstrated no change in the levels of these miRNAs [1], it is not likely that the changes in these six miRNA in body fluids from ALS patents are disease-specific. Although all of them are associated with motor neuron homeostasis, their roles in the pathogenetic mechanism of sporadic ALS are largely unknown. 
Table 3. miRNAs associated with motor neuron homeostasis and considered as biomarker candidates of sporadic ALS. AD: Alzheimer disease, PBL: peripheral blood leukocytes.

\begin{tabular}{|c|c|c|c|c|c|c|}
\hline miRNA & $\begin{array}{l}\text { Changes in } \\
\text { Levels }\end{array}$ & $\begin{array}{c}\text { Kinds of } \\
\text { Body Fluids }\end{array}$ & \multicolumn{2}{|c|}{ Patients (Origin and Number) } & Disease Specificity & Reference \\
\hline \multirow{2}{*}{ miR-9 } & \multirow{2}{*}{ Increase } & Plasma & American & $\begin{array}{c}50 \text { sporadic ALS } \\
50 \mathrm{AD} \\
50 \mathrm{PD} \\
50 \mathrm{FTLD} \\
50 \text { control subjects }\end{array}$ & \multirow{2}{*}{ Low (not disease-specific) } & [151] \\
\hline & & PBL & Slovenian & $\begin{array}{c}77 \text { sporadic ALS } \\
7 \text { familial ALS } \\
27 \text { control subjects }\end{array}$ & & [153] \\
\hline miR-124 & Increase & CSF & British & $\begin{array}{c}32 \text { sporadic ALS } \\
6 \mathrm{MS} \\
10 \text { control subjects }\end{array}$ & Low (not disease-specific) & [152] \\
\hline \multirow[t]{2}{*}{ miR-146a } & Increase & PBMCs & American & $\begin{array}{c}22 \text { sporadic ALS } \\
4 \text { familial ALS } \\
24 \text { control subjects }\end{array}$ & \multirow[t]{2}{*}{$\begin{array}{l}\text { Low (inconsistent results, not } \\
\text { disease-specific) }\end{array}$} & [154] \\
\hline & Decrease & Serum & Italian & $\begin{array}{l}14 \text { sporadic ALS } \\
8 \text { control subjects }\end{array}$ & & [155] \\
\hline $\operatorname{miR}-128$ & Decrease & Whole blood & Italian & $\begin{array}{c}50 \text { sporadic ALS } \\
15 \text { control subjects }\end{array}$ & Low (not disease-specific) & [156] \\
\hline \multirow[b]{2}{*}{ miR-183 } & \multirow[b]{2}{*}{ Decrease } & Whole blood & Italian & $\begin{array}{c}50 \text { sporadic ALS } \\
15 \text { control subjects }\end{array}$ & \multirow[b]{2}{*}{ Low (not disease-specific) } & [156] \\
\hline & & PBL & Chinese & $\begin{array}{c}83 \text { sporadic ALS } \\
24 \text { PD } \\
61 \text { control subjects }\end{array}$ & & [157] \\
\hline \multirow[t]{3}{*}{ miR-206 } & \multirow[t]{3}{*}{ Increase } & PBL & Slovenian & $\begin{array}{l}77 \text { sporadic ALS } \\
7 \text { familial ALS } \\
27 \text { control subjects }\end{array}$ & \multirow[t]{3}{*}{ Low (not disease-specific) } & [153] \\
\hline & & Serum & Spanish & $\begin{array}{c}12 \text { sporadic ALS } \\
12 \text { control subjects }\end{array}$ & & [158] \\
\hline & & Serum & British & $\begin{array}{c}27 \text { sporadic ALS } \\
36 \text { disease controls } \\
25 \text { control subjects }\end{array}$ & & [159] \\
\hline \multirow[t]{2}{*}{ miR-338-3p } & \multirow[t]{2}{*}{ Increase } & $\begin{array}{l}\text { Serum } \\
\text { PBL } \\
\text { CSF }\end{array}$ & Italian & $\begin{array}{l}72 \text { sporadic ALS } \\
62 \text { control subjects }\end{array}$ & \multirow[t]{2}{*}{ Low (not disease-specific) } & [172] \\
\hline & & PBL & Italian & $\begin{array}{c}14 \text { sporadic ALS } \\
14 \text { control subjects }\end{array}$ & & [173] \\
\hline miR-133b & Increase & Serum & American & $\begin{array}{l}20 \text { sporadic ALS } \\
3 \text { familial ALS } \\
30 \text { control subjects }\end{array}$ & Low (not disease-specific) & [176] \\
\hline
\end{tabular}


Table 3. Cont.

\begin{tabular}{|c|c|c|c|c|c|c|}
\hline miRNA & $\begin{array}{l}\text { Changes in } \\
\text { Levels }\end{array}$ & $\begin{array}{l}\text { Kinds of } \\
\text { Body Fluids }\end{array}$ & \multicolumn{2}{|c|}{ Patients (Origin and Number) } & Disease Specificity & Reference \\
\hline \multicolumn{7}{|c|}{ Prognostic biomarkers } \\
\hline miR-206 & Increase & Plasma & Brazilian & $\begin{array}{l}39 \text { sporadic ALS } \\
39 \text { control subjects }\end{array}$ & $\begin{array}{l}\text { High (correlation with Medical } \\
\text { Research Council Score) }\end{array}$ & [178] \\
\hline \multirow{3}{*}{ miR-9 } & \multirow{3}{*}{ Increase } & Plasma & American & $\begin{array}{c}50 \text { sporadic ALS } \\
50 \mathrm{AD} \\
50 \mathrm{PD} \\
50 \mathrm{FTLD} \\
50 \text { control subjects }\end{array}$ & \multirow{3}{*}{ Possible (More studies are needed) } & [151] \\
\hline & & CSF & British & $\begin{array}{c}32 \text { sporadic ALS } \\
6 \mathrm{MS} \\
10 \text { control subjects }\end{array}$ & & [152] \\
\hline & & PBL & Slovenian & $\begin{array}{c}77 \text { sporadic ALS } \\
7 \text { familial ALS } \\
27 \text { control subjects }\end{array}$ & & [153] \\
\hline miR-133b & Increase & Serum & American & $\begin{array}{c}20 \text { sporadic ALS } \\
3 \text { familial ALS } \\
30 \text { control subjects }\end{array}$ & Possible (More studies are needed) & [176] \\
\hline \multicolumn{7}{|c|}{ Pharmacodynamic biomarkers } \\
\hline \multirow{3}{*}{ miR-9 } & \multirow{3}{*}{ Increase } & Plasma & American & $\begin{array}{c}50 \text { sporadic ALS } \\
50 \mathrm{AD} \\
50 \mathrm{PD} \\
50 \mathrm{FTLD} \\
50 \text { control subjects }\end{array}$ & \multirow{3}{*}{ Possible (More studies are needed) } & [151] \\
\hline & & CSF & British & $\begin{array}{c}32 \text { sporadic ALS } \\
6 \mathrm{MS} \\
10 \text { control subjects }\end{array}$ & & [152] \\
\hline & & PBL & Slovenian & $\begin{array}{l}77 \text { sporadic ALS } \\
7 \text { familial ALS } \\
27 \text { control subjects }\end{array}$ & & [153] \\
\hline \multirow{4}{*}{ miR-206 } & \multirow{4}{*}{ Increase } & Plasma & American & $\begin{array}{c}50 \text { sporadic ALS } \\
50 \mathrm{AD} \\
50 \mathrm{PD} \\
50 \mathrm{FTLD} \\
50 \text { control subjects }\end{array}$ & \multirow{4}{*}{ Possible (More studies are needed) } & [151] \\
\hline & & PBL & Slovenian & $\begin{array}{l}77 \text { sporadic ALS } \\
7 \text { familial ALS } \\
27 \text { control subjects }\end{array}$ & & [153] \\
\hline & & Serum & Spanish & $\begin{array}{c}12 \text { sporadic ALS } \\
12 \text { control subjects }\end{array}$ & & [158] \\
\hline & & Serum & British & $\begin{array}{c}27 \text { sporadic ALS } \\
36 \text { disease controls } \\
25 \text { control subjects }\end{array}$ & & [159] \\
\hline \multicolumn{7}{|c|}{ Disease progression biomarker } \\
\hline miR-206 & Increase & Serum & British & $\begin{array}{l}36 \text { disease controls } \\
25 \text { control subjects }\end{array}$ & $\begin{array}{l}\text { Low (no correlation with disease } \\
\text { progression) }\end{array}$ & [159] \\
\hline
\end{tabular}

\subsection{Prognostic Biomarkers}

High expression levels of COL19A1 mRNA in whole blood are associated with fast progression of the disease, especially sporadic ALS [177]. Therefore, COL19A1 mRNA may be a prognostic biomarker candidate. Higher expression levels of serum miR-206 are associated with a slower worsening of the Medical Research Council Score, which reflects muscles strength in ALS patients [178]; meanwhile, the expression levels of miR-9 in skeletal muscles are increased in the ALS patients with slow disease progression [179]. Conversely, the expression levels of miR-133b are negatively correlated with the vital capacity [176]. As miRNAs-including miR-9 and miR-146a-regulate the expression levels of NEFL [168], which is a prognostic biomarker candidate, these two miRNAs may be promising, but as yet have not established prognostic biomarker candidates.

\subsection{Disease Progression Biomarkers}

The expression levels of VEGFA, mRNA, and CCL2 mRNA in ALS patients with respiratory dysfunction or definite ALS patients based on El Escorial criteria are higher than those without respiratory dysfunction or probable/possible ALS patients [135], suggesting that the changes in the expression levels of VEGFA, mRNA, and CCL2 mRNA may be disease progression biomarkers of 
sporadic ALS. Although the expression levels of miR-206 in skeletal muscles are inversely correlated with the time from the symptom onset to muscle biopsy [179], the expression levels of miR-206 in serum do not significantly change with time [159].

Long non-coding RNAs (lncRNAs) are the transcripts of non-coding gene regions greater than 200 nucleotides in length. LncRNAs interact with RNAs, including mRNA, miRNA, and circRNA, and hence are suggested to play roles in ALS pathogenesis $[180,181]$. There is a report exploring the expression levels of lncRNAs extracted from PBMCs, indicating that 293 lncRNAs were significantly different in the expression levels between normal control subjects and sporadic ALS patients; 183 lncRNAs were upregulated, and the remaining 110 lncRNAs were downregulated [134].

Although many RNAs are proposed as biomarker candidates of sporadic ALS, none of them has been deemed reliable. Most of these studies merely compared the expression levels of molecules among normal control subjects, disease control patients, and ALS patients without mentioning the potential roles in the pathogenesis. Although studies based on disease-specific molecular mechanisms are required for the establishment of biomarkers of ALS, a lack of knowledge about molecular cascades leading motor neurons to death in ALS has limited the targeting of promising molecules. Moreover, the difficulty of detecting small amounts of RNAs and proteins that are released from motor neurons, which are progressively decreasing in number, has prevented the extensive scrutiny of biomarkers.

\section{Biomarker Candidates Based on Excitotoxicity in Sporadic ALS}

Excitotoxicity resulting from the dysregulation of glutamatergic signaling has long been proposed as one of the pathogenic mechanisms of both sporadic and familial ALS [182,183], historically because glutamate levels were increased in post mortem tissue [184] and CSF of ALS patients [185-187]. The upper motor neurons use glutamate as neurotransmitters and glutamate secreted from the presynaptic boutons in the axon terminal activates the glutamate receptors, such as the $\alpha$-amino-3-hydroxy-5-methyl-4-isoxazole propionic acid (AMPA) receptors and the $\mathrm{N}$-methyl-D-aspartate (NMDA) receptors in the dendritic spines of the lower motor neurons, thereby transmitting excitatory signals. The excitatory signals are terminated by the uptake of released glutamate into surrounding astrocytes and/or neurons through glutamate transporters, including EAAT2 (Figure 2) [182]. Therefore, increased extracellular glutamate or the altered function of glutamate receptors may lead to an excessive influx of extracellular ions, including $\mathrm{Ca}^{2+}$, into the lower motor neurons. Since an exaggerated increase of intracellular $\mathrm{Ca}^{2+}$ concentration is toxic to neurons, the prolonged over-excitation of glutamate receptors may ultimately lead to motor neuron death [183]. Therefore, an increase of glutamate secretion, a reduction of glutamate reuptake, or exaggerated ion influx through aberrant glutamate receptors may be a potential cause of excitotoxicity and cause the death of motor neurons. These lines of evidence suggest that changes in extracellular proteins and RNAs reflecting excitotoxic events would be potential biomarker candidates of sporadic ALS (Figure 3 and Table 4). 


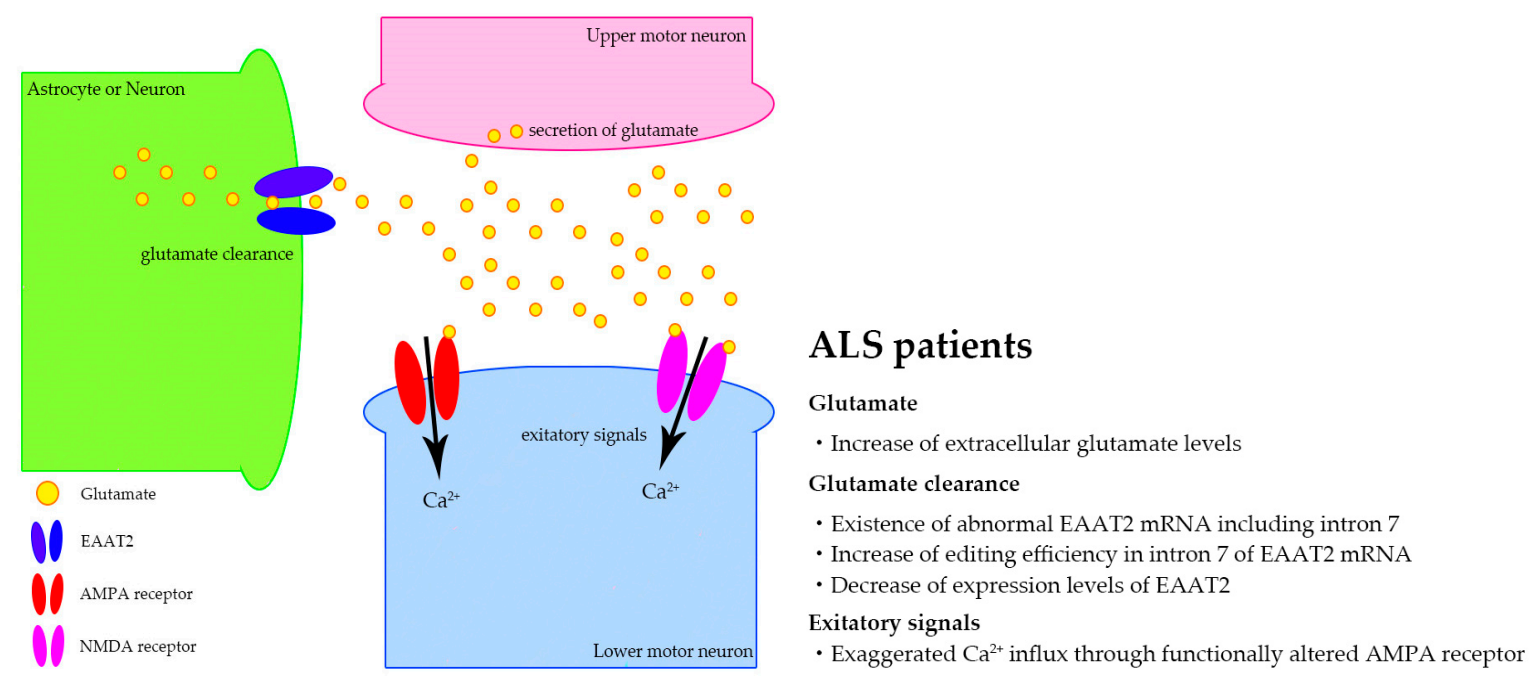

Figure 2. Excitotoxic mechanisms proposed in sporadic amyotrophic lateral sclerosis (ALS). In the synaptic cleft, glutamate is released from the axon terminal of the upper motor neuron (pink), and binds to the glutamate receptors such as the $\alpha$-amino-3-hydroxy-5-methyl-4-isoxazole propionic acid (AMPA) receptor and the $\mathrm{N}$-methyl-D-aspartate (NMDA) receptor expressed in the dendritic spines of the lower motor neuron (blue). The excitatory signals are regulated by glutamate transporters, including excitatory amino acid transporter 2 (EAAT2), which is expressed in astrocytes or neurons (green). An increase in glutamate levels in the postmortem tissue and cerebrospinal fluids, a decrease of glutamate clearance through EAAT2 due to aberrant mRNA processing, including intron 7 inclusion and an increase of editing efficiency in intron 7, and a decrease of expression levels of EAAT mRNA are shown. Also, motor neuron death due to exaggerated $\mathrm{Ca}^{2+}$ influx through functionally altered AMPA receptors is shown.

The change of extracellular glutamate levels has been reported. The levels of glutamate in the serum, plasma, and CSF of ALS patients have been shown to be significantly increased compared with those from normal control subjects and patients with Hirayama disease [188-190]. However, the levels of glutamate in CSF were increased only in approximately $40 \%$ of the patients [191], and high levels of glutamate in serum, plasma, and CSF were detected in ischemic stroke and MS patients [192,193] as well, suggesting that extracellular glutamate levels would not be disease-specific diagnostic biomarkers of sporadic ALS. Moreover, the levels of glutamate in plasma are not correlated with disease severity [188] or riluzole treatment [190], suggesting that the levels of glutamate may not serve as prognostic, predictive, or pharmacodynamic biomarkers.

Regarding the glutamate transporter dysfunction, decreased high-affinity glutamate transport [194], a decrease in expression levels of EAAT2 [195], the expression of abnormal intron 7-including EAAT2 mRNA [196], and an increase of EAAT2 pre-mRNA with RNA edited intron 7 [197] have been reported in ALS patients (Figure 2). Moreover, the inhibition of glutamate re-uptake with glutamate transporter inhibitors has been shown to be toxic to rat cortical and spinal motor neurons $[198,199]$. Mice lacking glt1, the rodent ortholog of human EAAT2, exhibited spontaneous seizure, the degeneration of hippocampal neurons, and early death [200]. However, several lines of evidence failed to demonstrate glutamate transporter dysfunction as a primary pathogenesis of ALS; intrathecal administration of glutamate transporter inhibitors causes no significant neuronal loss [201,202]. Furthermore, decreased expression levels of EAAT2 are not specific to ALS; they are also observed in other neurological diseases, including AD, ischemic hypoxia, and traumatic brain injury [203]. Aberrant RNA splicing of EAAT2 was also observed in non-neurological diseases [204]. Indeed, although the expression levels of miR-124 that regulate the expression levels of EAAT2 mRNA were significantly increased in the CSF of ALS patients [152], glutamate uptake in platelets were decreased not only in ALS patients, but also in AD and PD patients $[188,205,206]$, and the EAAT2 
levels in platelets from ALS patients were not statistically significantly different compared with those from control patients [207].

Regarding the altered function of glutamate receptors, exaggerated $\mathrm{Ca}^{2+}$ influx through the AMPA receptor and/or the NMDA receptor has been proposed to play a role in the death of motor neurons [208]. $\mathrm{Ca}^{2+}$ influx through AMPA receptors caused slow motor neuron death, and it has been reported that motor neurons were more vulnerable to AMPA receptor-mediated injury than spinal dorsal horn neurons in the primary neuronal culture, and the administration of AMPA receptor antagonists suppressed motor neuron death due to various causes [199,209]. Meanwhile, $\mathrm{Ca}^{2+}$ influx through the NMDA receptors is involved in rapid cell death such as epilepsy and encephalitis, and the administration of NMDA receptor agonists fails to cause neuronal loss $[198,210]$, suggesting that AMPA receptors may play a more significant role than NMDA receptors in slow motor neuron death, as seen in ALS patients (Figure 2) [210].

AMPA receptors are comprised of homotetramers or heterotetramers of GluA1, GluA2, GluA3, and GluA4. $\mathrm{Ca}^{2+}$ permeability of the AMPA receptor is determined by the presence of GluA2 with its glutamine/arginine $(\mathrm{Q} / \mathrm{R})$ site edited in the subunit assembly [211]. The CAG codon at the $\mathrm{Q} / \mathrm{R}$ site of the GluA2 transcript is converted to CIG by the activity of adenosine deaminase acting on RNA 2 (ADAR2), that specifically convert adenosine in the $Q / R$ site of GluA2 pre-mRNA into inosine [212]. This post-transcriptional A-to-I conversion is called RNA editing, which occurs ubiquitously but most actively in the mammalian CNS, including in humans [213]. Since inosine is recognized as guanosine during translation, A-to-I conversion at the $\mathrm{Q} / \mathrm{R}$ site of GluA2 mRNA results in the change from the glutamine codon (CAG) to that for arginine (CGG). Arginine (R) instead of glutamine $(\mathrm{Q})$ at the $\mathrm{Q} / \mathrm{R}$ site of GluA2 protein alters the ion-permeability property of the AMPA receptors, changing from $\mathrm{Ca}^{2+}$-permeable to $\mathrm{Ca}^{2+}$-impermeable [214-216]. As this conversion normally occurs at the $\mathrm{Q} / \mathrm{R}$ site of all the GluA2 expressed in the motor neurons, AMPA receptors expressed in motor neurons always include $\mathrm{Q} / \mathrm{R}$ site-edited GluA2 and AMPA receptors expressed in motor neurons, which are $\mathrm{Ca}^{2+}$-impermeable [214-216]. However, GluA2 mRNA that is expressed in the spinal motor neurons of sporadic ALS patients are not always edited at the $\mathrm{Q} / \mathrm{R}$ site because of the downregulation of ADAR2 [217,218]. The downregulation of ADAR2 is specific, and the expression levels of ADAR1 mRNA-another member of the ADAR family-in the motor neurons are not different between ALS and normal control subjects [218]. ADAR2 downregulation is specific in the motor neurons of sporadic ALS patients, and is not observed in other neurons of ALS patients or the motor neurons of normal control subjects and disease control patients, including patients with spinal and bulbar muscle atrophy (SBMA) and those with MSA, and transgenic rats with mutated human SOD1 [217-219]. Moreover, TDP-43 pathology, the pathological hallmark of sporadic ALS, is always associated with the motor neurons lacking immunoreactivity to ADAR2 in patients with sporadic ALS [220]. Furthermore, the roles of calpain in the mechanisms whereby TDP-43 mislocalization occurs in the ADAR2-lacking motor neurons were demonstrated in the conditional ADAR2 knockout mice [221]. The disease specificity and the link to TDP-43 pathology render ADAR2 downregulation a plausible hypothesis of the ALS pathogenesis.

It has been reported that RNAs with ADAR2-dependent sites in extracellular RNAs reflect intracellular ADAR2 activity in vitro [222], indicating that the change in ADAR2-dependent RNA editing of extracellular RNAs is a promising diagnostic biomarker of sporadic ALS. 


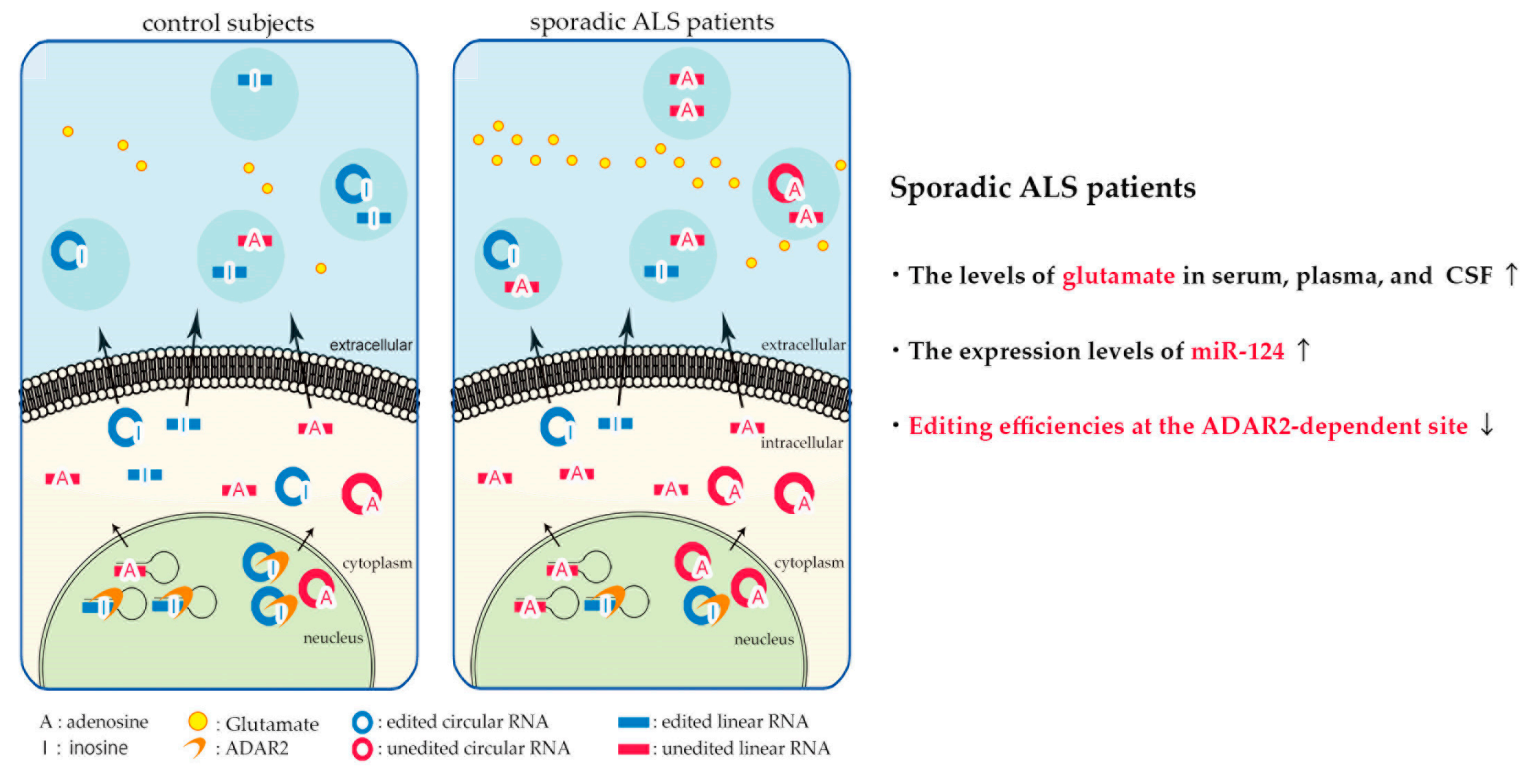

Figure 3. Biomarker candidates based on excitotoxicity in amyotrophic lateral sclerosis (ALS). A decrease of the RNA editing activity at the adenosine deaminase acting on RNA 2 (ADAR2)-dependent sites in the extracellular RNAs would be diagnostic, predictive, and pharmacodynamic biomarkers of sporadic ALS. This figure is modified from a previously published figure [223].

Table 4. Biomarker candidates based on excitotoxicity.

\begin{tabular}{|c|c|c|c|c|}
\hline & Changes in Levels & $\begin{array}{l}\text { Kinds of Body } \\
\text { Fluids }\end{array}$ & Reliability & Reference \\
\hline \multicolumn{5}{|c|}{ Diagnostic biomarkers } \\
\hline Glutamate & Increase & $\begin{array}{c}\text { Serum } \\
\text { Plasma } \\
\text { CSF }\end{array}$ & Low (not disease-specific) & [188-191] \\
\hline $\mathrm{miR}-124$ & Increase & CSF & Low (not disease-specific) & [152] \\
\hline $\begin{array}{l}\text { Editing efficiencies at the } \\
\text { ADAR2-dependent sites }\end{array}$ & Decrease & In vitro & $\begin{array}{c}\text { Possible (More studies are } \\
\text { needed) }\end{array}$ & [223] \\
\hline \multicolumn{5}{|c|}{ Prognostic biomarkers } \\
\hline Glutamate & Increase & Plasma & Low & [188] \\
\hline \multicolumn{5}{|c|}{ Predictive biomarkers } \\
\hline Glutamate & Increase & Plasma & Low & [191] \\
\hline $\begin{array}{l}\text { Editing efficiencies at the } \\
\text { ADAR2-dependent sites }\end{array}$ & Decrease & In vitro & $\begin{array}{l}\text { Possible (More studies } \\
\text { are needed) }\end{array}$ & [223] \\
\hline \multicolumn{5}{|c|}{ Pharmacodynamic biomarkers } \\
\hline Glutamate & Increase & Plasma & Low & [191] \\
\hline $\begin{array}{l}\text { Editing efficiencies at the } \\
\text { ADAR2-dependent sites }\end{array}$ & Decrease & In vitro & $\begin{array}{c}\text { Possible (More studies are } \\
\text { needed) }\end{array}$ & [223] \\
\hline
\end{tabular}

ADAR2 downregulation with expression of Q/R site-unedited GluA2 mRNA was reported in the motor neurons of familial ALS patients carrying the FUS ${ }^{\mathrm{P} 525 \mathrm{~L}}$ mutation as in sporadic ALS [223]. In addition, exaggerated $\mathrm{Ca}^{2+}$ influx through AMPA receptors [224] and ADAR2 mislocalization from the nucleus to the cytoplasm, with inactive A-to-I conversion, have been reported to be associated with enhanced hexanucleotide repeat expansion in C9ORF72 [225]. Therefore, biomarker candidates based on excitotoxicity would be biomarkers of some familial ALS. Moreover, therapy based on the correction of fatal molecular mechanisms induced by the downregulation of ADAR2 has been developed, including the adeno-associated virus vector-based ADAR2 gene therapy [226] and the inhibition of increased $\mathrm{Ca}^{2+}$ influx through abnormal AMPA receptors with the AMPA receptor antagonist perampanel [227], and we will know the results of clinical trials of perampanel by early 
2020. Therefore, the changes in editing efficiencies at the ADAR2-dependent A-to-I sites in extracellular RNAs may represent predictive, pharmacodynamic, and diagnostic biomarkers of sporadic ALS.

\section{Conclusion and Future Directions}

In this review, we summarized current knowledge regarding the role of extracellular proteins and RNAs as candidate biomarkers of neurodegenerative diseases, especially ALS. We currently have no reliable biomarkers of sporadic ALS, although the levels of A $\beta 42$, T-tau, and P-tau in AD and those of $\alpha$-synuclein in PD have been very promising biomarkers based on pathogenesis. As there is growing evidence that RNA dysregulation is involved in the pathogenesis of ALS, changes in the expression levels and processing of extracellular RNAs, reflecting excitotoxicity, would be very promising diagnostic, predictive, and/or pharmacodynamic biomarkers.

Author Contributions: S.K. and A.T. supervised the project. T.H. and T.Y. wrote the main text and produced the figures. All authors discussed the results and reviewed the manuscript.

Funding: A part of this study was supported by Strategic International Collaborative Research Program (SICORP) [grant number 16jm0310026h0004] and donations.

Acknowledgments: We thank Megumi Akamatsu and Sayaka Teramoto, Ms. Keiko Izumi at the Tokyo Medical University for technical assistance. Furthermore, we would like to express our gratitude to Takeshi Iwatsubo at the Tokyo University, Japan, for kindly providing us with research facilities.

Conflicts of Interest: The authors declare no competing financial interests.

\section{Abbreviations}

$\begin{array}{ll}\text { AD } & \text { Alzheimer disease } \\ \text { PD } & \text { Parkinson disease } \\ \text { ALS } & \text { amyotrophic lateral sclerosis } \\ \text { CNS } & \text { central nervous system } \\ \text { TDP-43 } & \text { transactive response DNA/RNA binding protein of 43kDa } \\ \text { CSF } & \text { cerebrospinal fluids } \\ \text { A } \beta & \beta \text {-amyloid } \\ \text { SOD-1 } & \text { superoxide dismutase 1 } \\ \text { FUS } & \text { fused in sarcoma } \\ \text { C9ORF72 } & \text { chromosome } 9 \text { open reading frame 72 } \\ \text { miRNA } & \text { micro RNA } \\ \text { circRNA } & \text { circular RNA } \\ \text { RBP } & \text { RNA binding protein } \\ \text { MVBs } & \text { multivesicular bodies } \\ \text { A-to-I } & \text { adenosine-to-inosine } \\ \text { RNA editing } & \text { A-to-I conversion of RNA } \\ \text { ADAR1 } & \text { adenosine deaminase acting on RNA 1 } \\ \text { PET } & \text { positron emission tomography } \\ \text { DAT-SPECT } & \text { dopamine transporter single-photon emission computed tomography } \\ \text { MIBG } & \text { meta-iodobenzylguanidine } \\ \text { A } 342 & 42 \text { amino acid form of A } \beta \\ \text { T-tau } & \text { total tau } \\ \text { P-tau } & \text { phosphorylated tau } \\ \text { NEFL } & \text { neurofilament light chain }\end{array}$




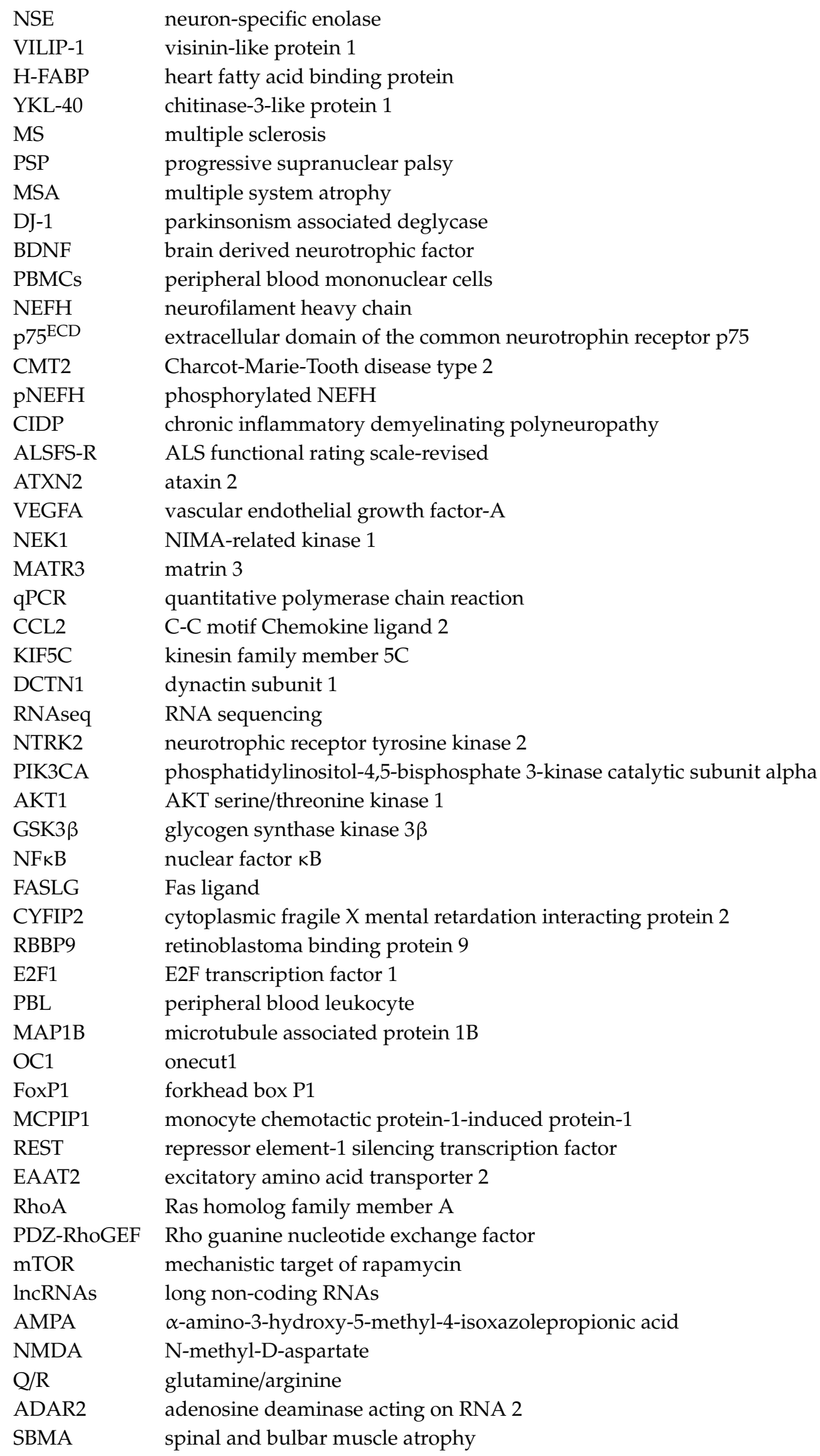

\section{References}

1. Quinlan, S.; Kenny, A.; Medina, M.; Engel, T.; Jimenez-Mateos, E.M. Micrornas in neurodegenerative diseases. Int. Rev. Cell Mol. Biol. 2017, 334, 309-343. [PubMed] 
2. Maniati, M.S.; Maniati, M.; Yousefi, T.; Ahmadi-Ahangar, A.; Tehrani, S.S. New insights into the role of micrornas and long noncoding rnas in most common neurodegenerative diseases. J. Cell. Biochem. 2019. [CrossRef] [PubMed]

3. Quek, C.; Hill, A.F. The role of extracellular vesicles in neurodegenerative diseases. Biochem. Biophys. Res. Commun. 2017, 483, 1178-1186. [CrossRef] [PubMed]

4. Biomarkers Definitions Working Group. Biomarkers and surrogate endpoints: Preferred definitions and conceptual framework. Clin. Pharmacol. Ther. 2001, 69, 89-95.

5. Van den Berg, L.H.; Sorenson, E.; Gronseth, G.; Macklin, E.A.; Andrews, J.; Baloh, R.H.; Benatar, M.; Berry, J.D.; Chio, A.; Corcia, P.; et al. Revised airlie house consensus guidelines for design and implementation of als clinical trials. Neurology 2019. [CrossRef] [PubMed]

6. Rappa, G.; Puglisi, C.; Santos, M.F.; Forte, S.; Memeo, L.; Lorico, A. Extracellular vesicles from thyroid carcinoma: The new frontier of liquid biopsy. Int. J. Mol. Sci. 2019, 20, 1114. [CrossRef] [PubMed]

7. Raposo, G.; Stoorvogel, W. Extracellular vesicles: Exosomes, microvesicles, and friends. J. Cell Biol. 2013, 200, $373-383$. [CrossRef] [PubMed]

8. Candelario, K.M.; Steindler, D.A. The role of extracellular vesicles in the progression of neurodegenerative disease and cancer. Trends Mol. Med. 2014, 20, 368-374. [CrossRef]

9. Caruso Bavisotto, C.; Scalia, F.; Marino Gammazza, A.; Carlisi, D.; Bucchieri, F.; Conway de Macario, E.; Macario, A.J.L.; Cappello, F.; Campanella, C. Extracellular vesicle-mediated cell(-)cell communication in the nervous system: Focus on neurological diseases. Int. J. Mol. Sci. 2019, 20, 434. [CrossRef]

10. Brown, R.H.; Al-Chalabi, A. Amyotrophic lateral sclerosis. N. Engl. J. Med. 2017, 377, 162-172. [CrossRef]

11. Chio, A.; Logroscino, G.; Hardiman, O.; Swingler, R.; Mitchell, D.; Beghi, E.; Traynor, B.G.; Eurals, C. Prognostic factors in als: A critical review. Amyotroph. Lateral. Scler. 2009, 10, 310-323. [CrossRef] [PubMed]

12. Chio, A.; Logroscino, G.; Traynor, B.J.; Collins, J.; Simeone, J.C.; Goldstein, L.A.; White, L.A. Global epidemiology of amyotrophic lateral sclerosis: A systematic review of the published literature. Neuroepidemiology 2013, 41, 118-130. [CrossRef] [PubMed]

13. Al-Chalabi, A.; Hardiman, O. The epidemiology of als: A conspiracy of genes, environment and time. Nat. Rev. Neurol. 2013, 9, 617-628. [CrossRef] [PubMed]

14. Taylor, J.P.; Brown, R.H., Jr.; Cleveland, D.W. Decoding als: From genes to mechanism. Nature 2016, 539, $197-206$. [CrossRef] [PubMed]

15. Recabarren-Leiva, D.; Alarcon, M. New insights into the gene expression associated to amyotrophic lateral sclerosis. Life Sci. 2018, 193, 110-123. [CrossRef] [PubMed]

16. Arai, T.; Hasegawa, M.; Akiyama, H.; Ikeda, K.; Nonaka, T.; Mori, H.; Mann, D.; Tsuchiya, K.; Yoshida, M.; Hashizume, Y.; et al. Tdp-43 is a component of ubiquitin-positive tau-negative inclusions in frontotemporal lobar degeneration and amyotrophic lateral sclerosis. Biochem. Biophys. Res. Commun. 2006, 351, 602-611. [CrossRef]

17. Neumann, M.; Sampathu, D.M.; Kwong, L.K.; Truax, A.C.; Micsenyi, M.C.; Chou, T.T.; Bruce, J.; Schuck, T.; Grossman, M.; Clark, C.M.; et al. Ubiquitinated tdp-43 in frontotemporal lobar degeneration and amyotrophic lateral sclerosis. Science 2006, 314, 130-133. [CrossRef]

18. Brooks, B.R.; Miller, R.G.; Swash, M.; Munsat, T.L.; World Federation of Neurology Research Group on Motor Neuron Diseases. El escorial revisited: Revised criteria for the diagnosis of amyotrophic lateral sclerosis. Amyotroph. Lateral Scler. Other Motor Neuron Disord. 2000, 1, 293-299. [CrossRef]

19. De Carvalho, M.; Dengler, R.; Eisen, A.; England, J.D.; Kaji, R.; Kimura, J.; Mills, K.; Mitsumoto, H.; Nodera, H.; Shefner, J.; et al. Electrodiagnostic criteria for diagnosis of als. Clin. Neurophysiol. 2008, 119, 497-503. [CrossRef]

20. Chiò, A. Risk factors in the early diagnosis of als: European epidemiological studies. Amyotroph. Lateral Scler. Other Motor Neuron Disord. 2000, 1, S13-S18. [CrossRef]

21. Cellura, E.; Spataro, R.; Taiello, A.C.; La Bella, V. Factors affecting the diagnostic delay in amyotrophic lateral sclerosis. Clin. Neurol. Neurosurg. 2012, 114, 550-554. [CrossRef] [PubMed]

22. Swash, M.; Ingram, D. Preclinical and subclinical events in motor neuron disease. J. Neurol. Neurosurg. Psychiatry 1988, 51, 165-168. [CrossRef] [PubMed]

23. Logroscino, G.; Traynor, B.J.; Hardiman, O.; Chio, A.; Mitchell, D.; Swingler, R.J.; Millul, A.; Benn, E.; Beghi, E.; Eurals, E. Incidence of amyotrophic lateral sclerosis in europe. J. Neurol. Neurosurg. Psychiatry 2010, 81, 385-390. [CrossRef] [PubMed] 
24. Kim, K.M.; Abdelmohsen, K.; Mustapic, M.; Kapogiannis, D.; Gorospe, M. Rna in extracellular vesicles. Wiley Interdiscip. Rev. RNA 2017, 8. [CrossRef] [PubMed]

25. Hoy, A.M.; Buck, A.H. Extracellular small rnas: What, where, why? Biochem. Soc. Trans. 2012, 40, 886-890. [CrossRef] [PubMed]

26. Gui, Y.; Liu, H.; Zhang, L.; Lv, W.; Hu, X. Altered microrna profiles in cerebrospinal fluid exosome in parkinson disease and alzheimer disease. Oncotarget 2015, 6, 37043-37053. [CrossRef] [PubMed]

27. Ricci, C.; Marzocchi, C.; Battistini, S. Micrornas as biomarkers in amyotrophic lateral sclerosis. Cells 2018, 7, 219. [CrossRef] [PubMed]

28. Butti, Z.; Patten, S.A. Rna dysregulation in amyotrophic lateral sclerosis. Front. Genet. 2018, 9, 712. [CrossRef] [PubMed]

29. Cocucci, E.; Racchetti, G.; Meldolesi, J. Shedding microvesicles: Artefacts no more. Trends Cell Biol. 2009, 19 , 43-51. [CrossRef] [PubMed]

30. Valadi, H.; Ekstrom, K.; Bossios, A.; Sjostrand, M.; Lee, J.J.; Lotvall, J.O. Exosome-mediated transfer of mrnas and micrornas is a novel mechanism of genetic exchange between cells. Nat. Cell Biol. 2007, 9, 654-659. [CrossRef] [PubMed]

31. Zernecke, A.; Bidzhekov, K.; Noels, H.; Shagdarsuren, E.; Gan, L.; Denecke, B.; Hristov, M.; Köppel, T.; Jahantigh, M.N.; Lutgens, E.; et al. Delivery of microrna-126 by apoptotic bodies induces cxcl12-dependent vascular protection. Sci. Signal 2009, 2, ra81. [CrossRef] [PubMed]

32. Akers, J.C.; Gonda, D.; Kim, R.; Carter, B.S.; Chen, C.C. Biogenesis of extracellular vesicles (ev): Exosomes, microvesicles, retrovirus-like vesicles, and apoptotic bodies. J. Neurooncol. 2013, 113, 1-11. [CrossRef] [PubMed]

33. Vickers, K.C.; Palmisano, B.T.; Shoucri, B.M.; Shamburek, R.D.; Remaley, A.T. Micrornas are transported in plasma and delivered to recipient cells by high-density lipoproteins. Nat. Cell Biol. 2011, 13, 423-433. [CrossRef] [PubMed]

34. Arroyo, J.D.; Chevillet, J.R.; Kroh, E.M.; Ruf, I.K.; Pritchard, C.C.; Gibson, D.F.; Mitchell, P.S.; Bennett, C.F.; Pogosova-Agadjanyan, E.L.; Stirewalt, D.L.; et al. Argonaute2 complexes carry a population of circulating micrornas independent of vesicles in human plasma. Proc. Natl. Acad. Sci. USA 2011, 108, 5003-5008. [CrossRef] [PubMed]

35. Wang, K.; Zhang, S.; Weber, J.; Baxter, D.; Galas, D.J. Export of micrornas and microrna-protective protein by mammalian cells. Nucleic Acids Res. 2010, 38, 7248-7259. [CrossRef] [PubMed]

36. Colombo, M.; Raposo, G.; Thery, C. Biogenesis, secretion, and intercellular interactions of exosomes and other extracellular vesicles. Annu. Rev. Cell Dev. Biol. 2014, 30, 255-289. [CrossRef]

37. Dluzen, D.F.; Noren Hooten, N.; Evans, M.K. Extracellular rna in aging. Wiley Interdiscip. Rev. RNA $2017,8$. [CrossRef]

38. Wei, Z.; Batagov, A.O.; Schinelli, S.; Wang, J.; Wang, Y.; El Fatimy, R.; Rabinovsky, R.; Balaj, L.; Chen, C.C.; Hochberg, F.; et al. Coding and noncoding landscape of extracellular rna released by human glioma stem cells. Nat. Commun. 2017, 8, 1145. [CrossRef]

39. Ha, M.; Kim, V.N. Regulation of microrna biogenesis. Nat. Rev. Mol. Cell Biol. 2014, 15, 509-524. [CrossRef]

40. Idda, M.L.; Munk, R.; Abdelmohsen, K.; Gorospe, M. Noncoding rnas in alzheimer's disease. Wiley Interdiscip. Rev. RNA 2018, 9, e1463. [CrossRef]

41. Nishikura, K. A-to-i editing of coding and non-coding rnas by adars. Nat. Rev. Mol. Cell Biol. 2016, 17, 83-96. [CrossRef] [PubMed]

42. Salta, E.; De Strooper, B. Non-coding rnas with essential roles in neurodegenerative disorders. Lancet Neurol. 2012, 11, 189-200. [CrossRef]

43. Wilusz, J.E. A 360 degrees view of circular rnas: From biogenesis to functions. Wiley Interdiscip. Rev. RNA 2018, 9, e1478. [CrossRef] [PubMed]

44. Li, Y.; Zheng, Q.; Bao, C.; Li, S.; Guo, W.; Zhao, J.; Chen, D.; Gu, J.; He, X.; Huang, S. Circular rna is enriched and stable in exosomes: A promising biomarker for cancer diagnosis. Cell Res. 2015, 25, 981-984. [CrossRef] [PubMed]

45. Zhang, Y.; Xue, W.; Li, X.; Zhang, J.; Chen, S.; Zhang, J.L.; Yang, L.; Chen, L.L. The biogenesis of nascent circular rnas. Cell Rep. 2016, 15, 611-624. [CrossRef] [PubMed] 
46. Ivanov, A.; Memczak, S.; Wyler, E.; Torti, F.; Porath, H.T.; Orejuela, M.R.; Piechotta, M.; Levanon, E.Y.; Landthaler, M.; Dieterich, C.; et al. Analysis of intron sequences reveals hallmarks of circular rna biogenesis in animals. Cell Rep. 2015, 10, 170-177. [CrossRef] [PubMed]

47. Errichelli, L.; Dini Modigliani, S.; Laneve, P.; Colantoni, A.; Legnini, I.; Capauto, D.; Rosa, A.; De Santis, R.; Scarfo, R.; Peruzzi, G.; et al. Fus affects circular rna expression in murine embryonic stem cell-derived motor neurons. Nat. Commun. 2017, 8, 14741. [CrossRef]

48. Jeck, W.R.; Sorrentino, J.A.; Wang, K.; Slevin, M.K.; Burd, C.E.; Liu, J.; Marzluff, W.F.; Sharpless, N.E. Circular rnas are abundant, conserved, and associated with alu repeats. RNA 2013, 19, 141-157. [CrossRef]

49. Salzman, J.; Gawad, C.; Wang, P.L.; Lacayo, N.; Brown, P.O. Circular rnas are the predominant transcript isoform from hundreds of human genes in diverse cell types. PLoS ONE 2012, 7, e30733. [CrossRef]

50. Rybak-Wolf, A.; Stottmeister, C.; Glazar, P.; Jens, M.; Pino, N.; Giusti, S.; Hanan, M.; Behm, M.; Bartok, O.; Ashwal-Fluss, R.; et al. Circular rnas in the mammalian brain are highly abundant, conserved, and dynamically expressed. Mol. Cell 2015, 58, 870-885. [CrossRef]

51. Gruner, H.; Cortes-Lopez, M.; Cooper, D.A.; Bauer, M.; Miura, P. Circrna accumulation in the aging mouse brain. Sci. Rep. 2016, 6, 38907. [CrossRef] [PubMed]

52. Scheltens, P.; Blennow, K.; Breteler, M.M.B.; de Strooper, B.; Frisoni, G.B.; Salloway, S.; Van der Flier, W.M. Alzheimer's disease. Lancet 2016, 388, 505-517. [CrossRef]

53. Kalia, L.V.; Lang, A.E. Parkinson's disease. Lancet 2015, 386, 896-912. [CrossRef]

54. Rajendran, L.; Honsho, M.; Zahn, T.R.; Keller, P.; Geiger, K.D.; Verkade, P.; Simons, K. Alzheimer's disease beta-amyloid peptides are released in association with exosomes. Proc. Natl. Acad. Sci. USA 2006, 103, 11172-11177. [CrossRef] [PubMed]

55. Olsson, B.; Lautner, R.; Andreasson, U.; Öhrfelt, A.; Portelius, E.; Bjerke, M.; Hölttä, M.; Rosén, C.; Olsson, C.; Strobel, G.; et al. Csf and blood biomarkers for the diagnosis of alzheimer's disease: A systematic review and meta-analysis. Lancet Neurol. 2016, 15, 673-684. [CrossRef]

56. Tapiola, T.; Alafuzoff, I.; Herukka, S.K.; Parkkinen, L.; Hartikainen, P.; Soininen, H.; Pirttilä, T. Cerebrospinal fluid $\beta$-amyloid 42 and tau proteins as biomarkers of alzheimer-type pathologic changes in the brain. Arch. Neurol. 2009, 66, 382-389. [CrossRef]

57. DeSouza, L.C.; Lamari, F.; Belliard, S.; Jardel, C.; Houillier, C.; De Paz, R.; Dubois, B.; Sarazin, M. Cerebrospinal fluid biomarkers in the differential diagnosis of alzheimer's disease from other cortical dementias. J. Neurol. Neurosurg. Psychiatry 2011, 82, 240-246. [CrossRef]

58. Tzen, K.Y.; Yang, S.Y.; Chen, T.F.; Cheng, T.W.; Horng, H.E.; Wen, H.P.; Huang, Y.Y.; Shiue, C.Y.; Chiu, M.J. Plasma abeta but not tau is related to brain pib retention in early alzheimer's disease. ACS Chem. Neurosci. 2014, 5, 830-836. [CrossRef]

59. Nakamura, A.; Kaneko, N.; Villemagne, V.L.; Kato, T.; Doecke, J.; Dore, V.; Fowler, C.; Li, Q.X.; Martins, R.; Rowe, C.; et al. High performance plasma amyloid-beta biomarkers for alzheimer's disease. Nature 2018, 554, 249-254. [CrossRef]

60. Zetterberg, H.; Wilson, D.; Andreasson, U.; Minthon, L.; Blennow, K.; Randall, J.; Hansson, O. Plasma tau levels in alzheimer's disease. Alzheimers Res. Ther. 2013, 5, 9. [CrossRef]

61. Mielke, M.M.; Hagen, C.E.; Xu, J.; Chai, X.; Vemuri, P.; Lowe, V.J.; Airey, D.C.; Knopman, D.S.; Roberts, R.O.; Machulda, M.M.; et al. Plasma phospho-tau181 increases with alzheimer's disease clinical severity and is associated with tau- and amyloid-positron emission tomography. Alzheimers Dement 2018, 14, 989-997. [CrossRef] [PubMed]

62. Preische, O.; Schultz, S.A.; Apel, A.; Kuhle, J.; Kaeser, S.A.; Barro, C.; Graber, S.; Kuder-Buletta, E.; LaFougere, C.; Laske, C.; et al. Serum neurofilament dynamics predicts neurodegeneration and clinical progression in presymptomatic alzheimer's disease. Nat. Med. 2019, 25, 277-283. [CrossRef] [PubMed]

63. Rosengren, L.E.; Karlsson, J.E.; Karlsson, J.O.; Persson, L.; Wikkelsø, C. Patients with amyotrophic lateral sclerosis and other neurodegenerative diseases have increased levels of neurofilament protein in csf. J. Neurochem. 1996, 67, 2013-2018. [CrossRef] [PubMed]

64. Weston, P.S.J.; Poole, T.; Ryan, N.S.; Nair, A.; Liang, Y.; Macpherson, K.; Druyeh, R.; Malone, I.B.; Ahsan, R.L.; Pemberton, H.; et al. Serum neurofilament light in familial alzheimer disease: A marker of early neurodegeneration. Neurology 2017, 89, 2167-2175. [CrossRef] [PubMed] 
65. Mattsson, N.; Andreasson, U.; Zetterberg, H.; Blennow, K.; Alzheimer's Disease Neuroimaging Initiative. Association of plasma neurofilament light with neurodegeneration in patients with alzheimer disease. JAMA Neurol. 2017, 74, 557-566. [CrossRef] [PubMed]

66. Zetterberg, H. Blood-based biomarkers for alzheimer's disease-an update. J. Neurosci. Methods 2019, 319, 2-6. [CrossRef] [PubMed]

67. Hoffmann, J.; Janowitz, D.; Van der Auwera, S.; Wittfeld, K.; Nauck, M.; Friedrich, N.; Habes, M.; Davatzikos, C.; Terock, J.; Bahls, M.; et al. Association between serum neuron-specific enolase, age, overweight, and structural mri patterns in 901 subjects. Transl. Psychiatry 2017, 7, 1272. [CrossRef] [PubMed]

68. Blennow, K.; Wallin, A.; Ekman, R. Neuron specific enolase in cerebrospinal fluid: A biochemical marker for neuronal degeneration in dementia disorders? J. Neural Transm. Park. Dis. Dement. Sect. 1994, 8, 183-191. [CrossRef] [PubMed]

69. Palumbo, B.; Siepi, D.; Sabalich, I.; Tranfaglia, C.; Parnetti, L. Cerebrospinal fluid neuron-specific enolase: A further marker of alzheimer's disease? Funct. Neurol. 2008, 23, 93-96.

70. Schmidt, F.M.; Mergl, R.; Stach, B.; Jahn, I.; Gertz, H.J.; Schonknecht, P. Elevated levels of cerebrospinal fluid neuron-specific enolase (nse) in alzheimer's disease. Neurosci. Lett. 2014, 570, 81-85. [CrossRef]

71. Parnetti, L.; Palumbo, B.; Cardinali, L.; Loreti, F.; Chionne, F.; Cecchetti, R.; Senin, U. Cerebrospinal fluid neuron-specific enolase in alzheimer's disease and vascular dementia. Neurosci. Lett. 1995, 183, $43-45$. [PubMed]

72. Rosen, C.; Mattsson, N.; Johansson, P.M.; Andreasson, U.; Wallin, A.; Hansson, O.; Johansson, J.O.; Lamont, J.; Svensson, J.; Blennow, K.; et al. Discriminatory analysis of biochip-derived protein patterns in csf and plasma in neurodegenerative diseases. Front. Aging Neurosci. 2011, 3, 1. [CrossRef] [PubMed]

73. Chaves, M.L.; Camozzato, A.L.; Ferreira, E.D.; Piazenski, I.; Kochhann, R.; Dall'Igna, O.; Mazzini, G.S.; Souza, D.O; Portela, L.V. Serum levels of s100b and nse proteins in alzheimer's disease patients. J. Neuroinflammation 2010, 7, 6. [CrossRef] [PubMed]

74. Lee, J.M.; Blennow, K.; Andreasen, N.; Laterza, O.; Modur, V.; Olander, J.; Gao, F.; Ohlendorf, M.; Ladenson, J.H. The brain injury biomarker vlp-1 is increased in the cerebrospinal fluid of alzheimer disease patients. Clin. Chem. 2008, 54, 1617-1623. [CrossRef] [PubMed]

75. Tarawneh, R.; D’Angelo, G.; Macy, E.; Xiong, C.; Carter, D.; Cairns, N.J.; Fagan, A.M.; Head, D.; Mintun, M.A.; Ladenson, J.H.; et al. Visinin-like protein-1: Diagnostic and prognostic biomarker in alzheimer disease. Ann. Neurol. 2011, 70, 274-285. [CrossRef] [PubMed]

76. Luo, X.; Hou, L.; Shi, H.; Zhong, X.; Zhang, Y.; Zheng, D.; Tan, Y.; Hu, G.; Mu, N.; Chan, J.; et al. Csf levels of the neuronal injury biomarker visinin-like protein-1 in alzheimer's disease and dementia with lewy bodies. J. Neurochem. 2013, 127, 681-690. [CrossRef] [PubMed]

77. Guo, L.H.; Alexopoulos, P.; Perneczky, R. Heart-type fatty acid binding protein and vascular endothelial growth factor: Cerebrospinal fluid biomarker candidates for alzheimer's disease. Eur. Arch. Psychiatry Clin. Neurosci. 2013, 263, 553-560. [CrossRef] [PubMed]

78. Olsson, B.; Hertze, J.; Lautner, R.; Zetterberg, H.; Nagga, K.; Hoglund, K.; Basun, H.; Annas, P.; Lannfelt, L.; Andreasen, N.; et al. Microglial markers are elevated in the prodromal phase of alzheimer's disease and vascular dementia. J. Alzheimers Dis. 2013, 33, 45-53. [CrossRef]

79. Craig-Schapiro, R.; Perrin, R.J.; Roe, C.M.; Xiong, C.; Carter, D.; Cairns, N.J.; Mintun, M.A.; Peskind, E.R.; Li, G.; Galasko, D.R.; et al. Ykl-40: A novel prognostic fluid biomarker for preclinical alzheimer's disease. Biol. Psychiatry 2010, 68, 903-912. [CrossRef]

80. Alcolea, D.; Carmona-Iragui, M.; Suarez-Calvet, M.; Sanchez-Saudinos, M.B.; Sala, I.; Anton-Aguirre, S.; Blesa, R.; Clarimon, J.; Fortea, J.; Lleo, A. Relationship between beta-secretase, inflammation and core cerebrospinal fluid biomarkers for alzheimer's disease. J. Alzheimers Dis. 2014, 42, 157-167. [CrossRef]

81. Mattsson, N.; Tabatabaei, S.; Johansson, P.; Hansson, O.; Andreasson, U.; Mansson, J.E.; Johansson, J.O.; Olsson, B.; Wallin, A.; Svensson, J.; et al. Cerebrospinal fluid microglial markers in alzheimer's disease: Elevated chitotriosidase activity but lack of diagnostic utility. Neuromolecular Med. 2011, 13, 151-159. [CrossRef] [PubMed]

82. Comabella, M.; Fernandez, M.; Martin, R.; Rivera-Vallve, S.; Borras, E.; Chiva, C.; Julia, E.; Rovira, A.; Canto, E.; Alvarez-Cermeno, J.C.; et al. Cerebrospinal fluid chitinase 3-like 1 levels are associated with conversion to multiple sclerosis. Brain 2010, 133, 1082-1093. [CrossRef] [PubMed] 
83. Kumar, S.; Reddy, P.H. Are circulating micrornas peripheral biomarkers for alzheimer's disease? Biochim. Biophys. Acta 2016, 1862, 1617-1627. [CrossRef] [PubMed]

84. Mushtaq, G.; Greig, N.H.; Anwar, F.; Zamzami, M.A.; Choudhry, H.; Shaik, M.M.; Tamargo, I.A.; Kamal, M.A. Mirnas as circulating biomarkers for alzheimer's disease and parkinson's disease. Med. Chem. 2016, 12, 217-225. [CrossRef] [PubMed]

85. Fransquet, P.D.; Ryan, J. Micro rna as a potential blood-based epigenetic biomarker for alzheimer's disease. Clin. Biochem. 2018, 58, 5-14. [CrossRef] [PubMed]

86. Swarbrick, S.; Wragg, N.; Ghosh, S.; Stolzing, A. Systematic review of mirna as biomarkers in alzheimer's disease. Mol. Neurobiol. 2019, 1-12. [CrossRef]

87. Ramakrishna, S.; Muddashetty, R.S. Emerging role of micrornas in dementia. J. Mol. Biol. 2019, 431, $1743-1762$. [CrossRef]

88. Noyce, A.J.; Lees, A.J.; Schrag, A.E. The prediagnostic phase of parkinson's disease. J. Neurol. Neurosurg. Psychiatry 2016, 87, 871-878. [CrossRef]

89. Maass, F.; Schulz, I.; Lingor, P.; Mollenhauer, B.; Bahr, M. Cerebrospinal fluid biomarker for parkinson's disease: An overview. Mol. Cell. Neurosci. 2018, 97, 60-66. [CrossRef]

90. Tokuda, T.; Salem, S.A.; Allsop, D.; Mizuno, T.; Nakagawa, M.; Qureshi, M.M.; Locascio, J.J.; Schlossmacher, M.G.; El-Agnaf, O.M. Decreased alpha-synuclein in cerebrospinal fluid of aged individuals and subjects with parkinson's disease. Biochem. Biophys. Res. Commun. 2006, 349, 162-166. [CrossRef]

91. Bidinosti, M.; Shimshek, D.R.; Mollenhauer, B.; Marcellin, D.; Schweizer, T.; Lotz, G.P.; Schlossmacher, M.G.; Weiss, A. Novel one-step immunoassays to quantify alpha-synuclein: Applications for biomarker development and high-throughput screening. J. Biol. Chem. 2012, 287, 33691-33705. [CrossRef] [PubMed]

92. Foulds, P.G.; Diggle, P.; Mitchell, J.D.; Parker, A.; Hasegawa, M.; Masuda-Suzukake, M.; Mann, D.M.; Allsop, D. A longitudinal study on alpha-synuclein in blood plasma as a biomarker for parkinson's disease. Sci. Rep. 2013, 3, 2540. [CrossRef] [PubMed]

93. Hong, Z.; Shi, M.; Chung, K.A.; Quinn, J.F.; Peskind, E.R.; Galasko, D.; Jankovic, J.; Zabetian, C.P.; Leverenz, J.B.; Baird, G.; et al. Dj-1 and alpha-synuclein in human cerebrospinal fluid as biomarkers of parkinson's disease. Brain 2010, 133, 713-726. [CrossRef] [PubMed]

94. Mollenhauer, B.; Locascio, J.J.; Schulz-Schaeffer, W.; Sixel-Döring, F.; Trenkwalder, C.; Schlossmacher, M.G. A-synuclein and tau concentrations in cerebrospinal fluid of patients presenting with parkinsonism: A cohort study. Lancet Neurol. 2011, 10, 230-240. [CrossRef]

95. El-Agnaf, O.M.; Salem, S.A.; Paleologou, K.E.; Curran, M.D.; Gibson, M.J.; Court, J.A.; Schlossmacher, M.G.; Allsop, D. Detection of oligomeric forms of alpha-synuclein protein in human plasma as a potential biomarker for parkinson's disease. FASEB J. 2006, 20, 419-425. [CrossRef] [PubMed]

96. Tokuda, T.; Qureshi, M.M.; Ardah, M.T.; Varghese, S.; Shehab, S.A.; Kasai, T.; Ishigami, N.; Tamaoka, A.; Nakagawa, M.; El-Agnaf, O.M. Detection of elevated levels of $\alpha$-synuclein oligomers in csf from patients with parkinson disease. Neurology 2010, 75, 1766-1772. [CrossRef] [PubMed]

97. Shahnawaz, M.; Tokuda, T.; Waragai, M.; Mendez, N.; Ishii, R.; Trenkwalder, C.; Mollenhauer, B.; Soto, C. Development of a biochemical diagnosis of parkinson disease by detection of alpha-synuclein misfolded aggregates in cerebrospinal fluid. JAMA Neurol. 2017, 74, 163-172. [CrossRef]

98. Hall, S.; Ohrfelt, A.; Constantinescu, R.; Andreasson, U.; Surova, Y.; Bostrom, F.; Nilsson, C.; Hakan, W.; Decraemer, H.; Nagga, K.; et al. Accuracy of a panel of 5 cerebrospinal fluid biomarkers in the differential diagnosis of patients with dementia and/or parkinsonian disorders. Arch. Neurol. 2012, 69, 1445-1452. [CrossRef]

99. Eusebi, P.; Giannandrea, D.; Biscetti, L.; Abraha, I.; Chiasserini, D.; Orso, M.; Calabresi, P.; Parnetti, L. Diagnostic utility of cerebrospinal fluid alpha-synuclein in parkinson's disease: A systematic review and meta-analysis. Mov. Disord. 2017, 32, 1389-1400. [CrossRef]

100. Magdalinou, N.K.; Paterson, R.W.; Schott, J.M.; Fox, N.C.; Mummery, C.; Blennow, K.; Bhatia, K.; Morris, H.R.; Giunti, P.; Warner, T.T.; et al. A panel of nine cerebrospinal fluid biomarkers may identify patients with atypical parkinsonian syndromes. J. Neurol. Neurosurg. Psychiatry 2015, 86, 1240-1247. [CrossRef]

101. Hansson, O.; Janelidze, S.; Hall, S.; Magdalinou, N.; Lees, A.J.; Andreasson, U.; Norgren, N.; Linder, J.; Forsgren, L.; Constantinescu, R.; et al. Blood-based nfl: A biomarker for differential diagnosis of parkinsonian disorder. Neurology 2017, 88, 930-937. [CrossRef] [PubMed] 
102. Lotankar, S.; Prabhavalkar, K.S.; Bhatt, L.K. Biomarkers for parkinson's disease: Recent advancement. Neurosci. Bull. 2017, 33, 585-597. [CrossRef]

103. Andersen, A.D.; Binzer, M.; Stenager, E.; Gramsbergen, J.B. Cerebrospinal fluid biomarkers for parkinson's disease - a systematic review. Acta Neurol. Scand. 2017, 135, 34-56. [CrossRef] [PubMed]

104. Singh, A.; Sen, D. Micrornas in parkinson's disease. Exp. Brain Res. 2017, 235, 2359-2374. [CrossRef] [PubMed]

105. Roser, A.E.; Caldi Gomes, L.; Schunemann, J.; Maass, F.; Lingor, P. Circulating mirnas as diagnostic biomarkers for parkinson's disease. Front. Neurosci. 2018, 12, 625. [CrossRef] [PubMed]

106. Pasinetti, G.M.; Ungar, L.H.; Lange, D.J.; Yemul, S.; Deng, H.; Yuan, X.; Brown, R.H.; Cudkowicz, M.E.; Newhall, K.; Peskind, E.; et al. Identification of potential csf biomarkers in als. Neurology 2006, 66, 1218-1222. [CrossRef]

107. Von Neuhoff, N.; Oumeraci, T.; Wolf, T.; Kollewe, K.; Bewerunge, P.; Neumann, B.; Brors, B.; Bufler, J.; Wurster, U.; Schlegelberger, B.; et al. Monitoring csf proteome alterations in amyotrophic lateral sclerosis: Obstacles and perspectives in translating a novel marker panel to the clinic. PLoS ONE 2012, 7, e44401. [CrossRef]

108. Chen, Y.; Liu, X.H.; Wu, J.J.; Ren, H.M.; Wang, J.; Ding, Z.T.; Jiang, Y.P. Proteomic analysis of cerebrospinal fluid in amyotrophic lateral sclerosis. Exp. Ther. Med. 2016, 11, 2095-2106. [CrossRef]

109. Leoni, E.; Bremang, M.; Mitra, V.; Zubiri, I.; Jung, S.; Lu, C.H.; Adiutori, R.; Lombardi, V.; Russell, C.; Koncarevic, S.; et al. Combined tissue-fluid proteomics to unravel phenotypic variability in amyotrophic lateral sclerosis. Sci. Rep. 2019, 9, 4478. [CrossRef]

110. Steinacker, P.; Hendrich, C.; Sperfeld, A.D.; Jesse, S.; von Arnim, C.A.; Lehnert, S.; Pabst, A.; Uttner, I.; Tumani, H.; Lee, V.M.; et al. Tdp-43 in cerebrospinal fluid of patients with frontotemporal lobar degeneration and amyotrophic lateral sclerosis. Arch. Neurol. 2008, 65, 1481-1487. [CrossRef]

111. Kasai, T.; Tokuda, T.; Ishigami, N.; Sasayama, H.; Foulds, P.; Mitchell, D.J.; Mann, D.M.; Allsop, D.; Nakagawa, M. Increased tdp-43 protein in cerebrospinal fluid of patients with amyotrophic lateral sclerosis. Acta Neuropathol. 2009, 117, 55-62. [CrossRef] [PubMed]

112. Noto, Y.; Shibuya, K.; Sato, Y.; Kanai, K.; Misawa, S.; Sawai, S.; Mori, M.; Uchiyama, T.; Isose, S.; Nasu, S.; et al. Elevated csf tdp-43 levels in amyotrophic lateral sclerosis: Specificity, sensitivity, and a possible prognostic value. Amyotroph. Lateral Scler. 2011, 12, 140-143. [CrossRef] [PubMed]

113. Hosokawa, M.; Arai, T.; Yamashita, M.; Tsuji, H.; Nonaka, T.; Masuda-Suzukake, M.; Tamaoka, A.; Hasegawa, M.; Akiyama, H. Differential diagnosis of amyotrophic lateral sclerosis from guillain-barre syndrome by quantitative determination of tdp-43 in cerebrospinal fluid. Int. J. Neurosci. 2014, 124, 344-349. [CrossRef] [PubMed]

114. Feneberg, E.; Steinacker, P.; Lehnert, S.; Schneider, A.; Walther, P.; Thal, D.R.; Linsenmeier, M.; Ludolph, A.C.; Otto, M. Limited role of free tdp-43 as a diagnostic tool in neurodegenerative diseases. Amyotroph. Lateral Scler. Frontotemporal Degener. 2014, 15, 351-356. [CrossRef] [PubMed]

115. Poesen, K.; Van Damme, P. Diagnostic and prognostic performance of neurofilaments in als. Front. Neurol. 2019, 9, 1167. [CrossRef] [PubMed]

116. Yuan, A.; Rao, M.V.; Veeranna; Nixon, R.A. Neurofilaments and neurofilament proteins in health and disease. Cold Spring Harb. Perspect. Biol. 2017, 9, a018309. [CrossRef] [PubMed]

117. Brettschneider, J.; Petzold, A.; Süssmuth, S.D.; Ludolph, A.C.; Tumani, H. Axonal damage markers in cerebrospinal fluid are increased in als. Neurology 2006, 66, 852-856. [CrossRef] [PubMed]

118. Boylan, K.; Yang, C.; Crook, J.; Overstreet, K.; Heckman, M.; Wang, Y.; Borchelt, D.; Shaw, G. Immunoreactivity of the phosphorylated axonal neurofilament $\mathrm{h}$ subunit (pnf-h) in blood of als model rodents and als patients: Evaluation of blood pnf-h as a potential als biomarker. J. Neurochem. 2009, 111, 1182-1191. [CrossRef] [PubMed]

119. Steinacker, P.; Feneberg, E.; Weishaupt, J.; Brettschneider, J.; Tumani, H.; Andersen, P.M.; von Arnim, C.A.; Bohm, S.; Kassubek, J.; Kubisch, C.; et al. Neurofilaments in the diagnosis of motoneuron diseases: A prospective study on 455 patients. J. Neurol. Neurosurg. Psychiatry 2016, 87, 12-20. [CrossRef] [PubMed]

120. Poesen, K.; De Schaepdryver, M.; Stubendorff, B.; Gille, B.; Muckova, P.; Wendler, S.; Prell, T.; Ringer, T.M.; Rhode, H.; Stevens, O.; et al. Neurofilament markers for als correlate with extent of upper and lower motor neuron disease. Neurology 2017, 88, 2302-2309. [CrossRef] [PubMed] 
121. Feneberg, E.; Oeckl, P.; Steinacker, P.; Verde, F.; Barro, C.; Van Damme, P.; Gray, E.; Grosskreutz, J.; Jardel, C.; Kuhle, J.; et al. Multicenter evaluation of neurofilaments in early symptom onset amyotrophic lateral sclerosis. Neurology 2018, 90, e22-e30. [CrossRef] [PubMed]

122. Li, D.W.; Ren, H.; Jeromin, A.; Liu, M.; Shen, D.; Tai, H.; Ding, Q.; Li, X.; Cui, L. Diagnostic performance of neurofilaments in chinese patients with amyotrophic lateral sclerosis: A prospective study. Front. Neurol. 2018, 9, 726. [CrossRef] [PubMed]

123. Gille, B.; De Schaepdryver, M.; Goossens, J.; Dedeene, L.; De Vocht, J.; Oldoni, E.; Goris, A.; Van Den Bosch, L.; Depreitere, B.; Claeys, K.G.; et al. Serum neurofilament light chain levels as a marker of upper motor neuron degeneration in patients with amyotrophic lateral sclerosis. Neuropathol. Appl. Neurobiol. 2019, 45, 291-304. [CrossRef] [PubMed]

124. Verde, F.; Steinacker, P.; Weishaupt, J.H.; Kassubek, J.; Oeckl, P.; Halbgebauer, S.; Tumani, H.; von Arnim, C.A.F.; Dorst, J.; Feneberg, E.; et al. Neurofilament light chain in serum for the diagnosis of amyotrophic lateral sclerosis. J. Neurol. Neurosurg. Psychiatry 2019, 90, 157-164. [CrossRef] [PubMed]

125. Matusica, D.; Alfonsi, F.; Turner, B.J.; Butler, T.J.; Shepheard, S.R.; Rogers, M.L.; Skeldal, S.; Underwood, C.K.; Mangelsdorf, M.; Coulson, E.J. Inhibition of motor neuron death in vitro and in vivo by a p75 neurotrophin receptor intracellular domain fragment. J. Cell Sci. 2016, 129, 517-530. [CrossRef] [PubMed]

126. Shepheard, S.R.; Chataway, T.; Schultz, D.W.; Rush, R.A.; Rogers, M.L. The extracellular domain of neurotrophin receptor p75 as a candidate biomarker for amyotrophic lateral sclerosis. PLoS ONE 2014, 9, e87398. [CrossRef] [PubMed]

127. Shepheard, S.R.; Wuu, J.; Cardoso, M.; Wiklendt, L.; Dinning, P.G.; Chataway, T.; Schultz, D.; Benatar, M.; Rogers, M.L. Urinary p75ecd: A prognostic, disease progression, and pharmacodynamic biomarker in als. Neurology 2017, 88, 1137-1143. [CrossRef]

128. Jia, R.; Shepheard, S.; Jin, J.; Hu, F.; Zhao, X.; Xue, L.; Xiang, L.; Qi, H.; Qu, Q.; Guo, F.; et al. Urinary extracellular domain of neurotrophin receptor $\mathrm{p} 75$ as a biomarker for amyotrophic lateral sclerosis in a chinese cohort. Sci. Rep. 2017, 7, 5127. [CrossRef]

129. Ibanez, C.F.; Simi, A. P75 neurotrophin receptor signaling in nervous system injury and degeneration: Paradox and opportunity. Trends Neurosci. 2012, 35, 431-440. [CrossRef]

130. Kumar, V.; Hasan, G.M.; Hassan, M.I. Unraveling the role of rna mediated toxicity of c9orf72 repeats in c9-ftd/als. Front. Neurosci. 2017, 11, 711. [CrossRef]

131. Gibson, S.B.; Downie, J.M.; Tsetsou, S.; Feusier, J.E.; Figueroa, K.P.; Bromberg, M.B.; Jorde, L.B.; Pulst, S.M. The evolving genetic risk for sporadic als. Neurology 2017, 89, 226-233. [CrossRef] [PubMed]

132. Van Rheenen, W.; Diekstra, F.P.; Harschnitz, O.; Westeneng, H.J.; van Eijk, K.R.; Saris, C.G.J.; Groen, E.J.N.; van Es, M.A.; Blauw, H.M.; van Vught, P.W.J.; et al. Whole blood transcriptome analysis in amyotrophic lateral sclerosis: A biomarker study. PLoS ONE 2018, 13, e0198874. [CrossRef] [PubMed]

133. Saris, C.G.; Horvath, S.; van Vught, P.W.; van Es, M.A.; Blauw, H.M.; Fuller, T.F.; Langfelder, P.; DeYoung, J.; Wokke, J.H.; Veldink, J.H.; et al. Weighted gene co-expression network analysis of the peripheral blood from amyotrophic lateral sclerosis patients. BMC Genom. 2009, 10, 405. [CrossRef] [PubMed]

134. Gagliardi, S.; Zucca, S.; Pandini, C.; Diamanti, L.; Bordoni, M.; Sproviero, D.; Arigoni, M.; Olivero, M.; Pansarasa, O.; Ceroni, M.; et al. Long non-coding and coding rnas characterization in peripheral blood mononuclear cells and spinal cord from amyotrophic lateral sclerosis patients. Sci. Rep. 2018, 8, 2378. [CrossRef] [PubMed]

135. Gupta, P.K.; Prabhakar, S.; Abburi, C.; Sharma, N.K.; Anand, A. Vascular endothelial growth factor-a and chemokine ligand ( $\mathrm{ccl} 2)$ genes are upregulated in peripheral blood mononuclear cells in indian amyotrophic lateral sclerosis patients. J. Neuroinflammation 2011, 9, 114. [CrossRef] [PubMed]

136. Kuzma-Kozakiewicz, M.; Kazmierczak, B.; Chudy, A.; Gajewska, B.; Baranczyk-Kuzma, A. Alteration of motor protein expression involved in bidirectional transport in peripheral blood mononuclear cells of patients with amyotrophic lateral sclerosis. Neurodegener. Dis. 2016, 16, 235-244. [CrossRef] [PubMed]

137. Nachmany, H.; Wald, S.; Abekasis, M.; Bulvik, S.; Weil, M. Two potential biomarkers identified in mesenchymal stem cells and leukocytes of patients with sporadic amyotrophic lateral sclerosis. Dis. Markers 2012, 32, 211-220. [CrossRef] [PubMed]

138. Sadanand, A.; Janardhanan, A.; Vanisree, A.J.; Pavai, T. Neurotrophin expression in lymphocytes: A powerful indicator of degeneration in parkinson's disease, amyotrophic lateral sclerosis and ataxia. J. Mol. Neurosci. 2018, 64, 224-232. [CrossRef] [PubMed] 
139. Storkebaum, E.; Lambrechts, D.; Carmeliet, P. Vegf: Once regarded as a specific angiogenic factor, now implicated in neuroprotection. Bioessays 2004, 26, 943-954. [CrossRef]

140. Oosthuyse, B.; Moons, L.; Storkebaum, E.; Beck, H.; Nuyens, D.; Brusselmans, K.; Van Dorpe, J.; Hellings, P.; Gorselink, M.; Heymans, S.; et al. Deletion of the hypoxia-response element in the vascular endothelial growth factor promoter causes motor neuron degeneration. Nat. Genet. 2001, 28, 131-138. [CrossRef] [PubMed]

141. Madrigal, J.L.; Leza, J.C.; Polak, P.; Kalinin, S.; Feinstein, D.L. Astrocyte-derived mcp-1 mediates neuroprotective effects of noradrenaline. J. Neurosci. 2009, 29, 263-267. [CrossRef] [PubMed]

142. Kanai, Y.; Okada, Y.; Tanaka, Y.; Harada, A.; Terada, S.; Hirokawa, N. Kif5c, a novel neuronal kinesin enriched in motor neurons. J. Neurosci. 2000, 20, 6374-6384. [CrossRef] [PubMed]

143. Kuzma-Kozakiewicz, M.; Chudy, A.; Kazmierczak, B.; Dziewulska, D.; Usarek, E.; Baranczyk-Kuzma, A. Dynactin deficiency in the cns of humans with sporadic als and mice with genetically determined motor neuron degeneration. Neurochem. Res. 2013, 38, 2463-2473. [CrossRef] [PubMed]

144. Knaepen, K.; Goekint, M.; Heyman, E.M.; Meeusen, R. Neuroplasticity-exercise-induced response of peripheral brain-derived neurotrophic factor: A systematic review of experimental studies in human subjects. Sports Med. 2010, 40, 765-801. [CrossRef] [PubMed]

145. Jackson, R.S., 2nd; Cho, Y.J.; Stein, S.; Liang, P. Cyfip2, a direct p53 target, is leptomycin-b sensitive. Cell Cycle 2007, 6, 95-103. [CrossRef] [PubMed]

146. Woitach, J.T.; Zhang, M.; Niu, C.H.; Thorgeirsson, S.S. A retinoblastoma-binding protein that affects cell-cycle control and confers transforming ability. Nat. Genet. 1998, 19, 371-374. [CrossRef] [PubMed]

147. Bose, S.; Cho, J. Role of chemokine ccl2 and its receptor ccr2 in neurodegenerative diseases. Arch. Pharm. Res. 2013, 36, 1039-1050. [CrossRef]

148. Wang, Z.; Zhou, W.; Zhou, B.; Zhang, J.; for Alzheimer's Disease Neuroimaging Initiative. Association of vascular endothelial growth factor levels in csf and cerebral glucose metabolism across the alzheimer's disease spectrum. Neurosci. Lett. 2018, 687, 276-279. [CrossRef]

149. Du, Y.; Wu, H.T.; Qin, X.Y.; Cao, C.; Liu, Y.; Cao, Z.Z.; Cheng, Y. Postmortem brain, cerebrospinal fluid, and blood neurotrophic factor levels in alzheimer's disease: A systematic review and meta-analysis. J. Mol. Neurosci. 2018, 65, 289-300. [CrossRef]

150. Hawley, Z.C.E.; Campos-Melo, D.; Droppelmann, C.A.; Strong, M.J. Motomirs: Mirnas in motor neuron function and disease. Front. Mol. Neurosci. 2017, 10, 127. [CrossRef]

151. Sheinerman, K.S.; Toledo, J.B.; Tsivinsky, V.G.; Irwin, D.; Grossman, M.; Weintraub, D.; Hurtig, H.I.; Chen-Plotkin, A.; Wolk, D.A.; McCluskey, L.F.; et al. Circulating brain-enriched micrornas as novel biomarkers for detection and differentiation of neurodegenerative diseases. Alzheimers Res. Ther. 2017, 9, 89. [CrossRef] [PubMed]

152. Waller, R.; Wyles, M.; Heath, P.R.; Kazoka, M.; Wollff, H.; Shaw, P.J.; Kirby, J. Small rna sequencing of sporadic amyotrophic lateral sclerosis cerebrospinal fluid reveals differentially expressed mirnas related to neural and glial activity. Front. Neurosci. 2017, 11, 731. [CrossRef] [PubMed]

153. Vrabec, K.; Bostjancic, E.; Koritnik, B.; Leonardis, L.; Dolenc Groselj, L.; Zidar, J.; Rogelj, B.; Glavac, D.; Ravnik-Glavac, M. Differential expression of several mirnas and the host genes aatk and dnm2 in leukocytes of sporadic als patients. Front. Mol. Neurosci. 2018, 11, 106. [CrossRef] [PubMed]

154. Butovsky, O.; Siddiqui, S.; Gabriely, G.; Lanser, A.J.; Dake, B.; Murugaiyan, G.; Doykan, C.E.; Wu, P.M.; Gali, R.R.; Iyer, L.K.; et al. Modulating inflammatory monocytes with a unique microrna gene signature ameliorates murine als. J. Clin. Invest. 2012, 122, 3063-3087. [CrossRef] [PubMed]

155. Tasca, E.; Pegoraro, V.; Merico, A.; Angelini, C. Circulating micrornas as biomarkers of muscle differentiation and atrophy in als. Clin. Neuropathol. 2016, 35, 22-30. [CrossRef] [PubMed]

156. Liguori, M.; Nuzziello, N.; Introna, A.; Consiglio, A.; Licciulli, F.; D’Errico, E.; Scarafino, A.; Distaso, E.; Simone, I.L. Dysregulation of micrornas and target genes networks in peripheral blood of patients with sporadic amyotrophic lateral sclerosis. Front. Mol. Neurosci. 2018, 11, 288. [CrossRef] [PubMed]

157. Chen, Y.; Wei, Q.; Chen, X.; Li, C.; Cao, B.; Ou, R.; Hadano, S.; Shang, H.F. Aberration of mirnas expression in leukocytes from sporadic amyotrophic lateral sclerosis. Front. Mol. Neurosci. 2016, 9, 69. [CrossRef]

158. Toivonen, J.M.; Manzano, R.; Olivan, S.; Zaragoza, P.; Garcia-Redondo, A.; Osta, R. Microrna-206: A potential circulating biomarker candidate for amyotrophic lateral sclerosis. PLoS ONE 2014, 9, e89065. [CrossRef] 
159. Waller, R.; Goodall, E.F.; Milo, M.; Cooper-Knock, J.; Da Costa, M.; Hobson, E.; Kazoka, M.; Wollff, H.; Heath, P.R.; Shaw, P.J.; et al. Serum mirnas mir-206, 143-3p and 374b-5p as potential biomarkers for amyotrophic lateral sclerosis (als). Neurobiol. Aging 2017, 55, 123-131. [CrossRef]

160. Vijayakumar, U.G.; Milla, V.; Cynthia Stafford, M.Y.; Bjourson, A.J.; Duddy, W.; Duguez, S.M. A systematic review of suggested molecular strata, biomarkers and their tissue sources in als. Front. Neurol. 2019, 10, 400. [CrossRef]

161. Dajas-Bailador, F.; Bonev, B.; Garcez, P.; Stanley, P.; Guillemot, F.; Papalopulu, N. Microrna-9 regulates axon extension and branching by targeting map1b in mouse cortical neurons. Nat. Neurosci. 2012, 25, 697. [CrossRef] [PubMed]

162. Otaegi, G.; Pollock, A.; Hong, J.; Sun, T. Microrna mir-9 modifies motor neuron columns by a tuning regulation of foxp1 levels in developing spinal cords. J. Neurosci. 2011, 31, 809-818. [CrossRef] [PubMed]

163. Luxenhofer, G.; Helmbrecht, M.S.; Langhoff, J.; Giusti, S.A.; Refojo, D.; Huber, A.B. Microrna-9 promotes the switch from early-born to late-born motor neuron populations by regulating onecut transcription factor expression. Dev. Biol. 2014, 386, 358-370. [CrossRef] [PubMed]

164. Haramati, S.; Chapnik, E.; Sztainberg, Y.; Eilam, R.; Zwang, R.; Gershoni, N.; McGlinn, E.; Heiser, P.W.; Wills, A.M.; Wirguin, I.; et al. Mirna malfunction causes spinal motor neuron disease. Proc. Natl. Acad. Sci. USA 2010, 107, 13111-13116. [CrossRef] [PubMed]

165. Xu, Y.; An, B.Y.; Xi, X.B.; Li, Z.W.; Li, F.Y. Microrna-9 controls apoptosis of neurons by targeting monocyte chemotactic protein-induced protein 1 expression in rat acute spinal cord injury model. Brain Res. Bull. 2016, 121, 233-240. [CrossRef] [PubMed]

166. Visvanathan, J.; Lee, S.; Lee, B.; Lee, J.W.; Lee, S.K. The microrna mir-124 antagonizes the anti-neural rest/scp1 pathway during embryonic cns development. Genes Dev. 2007, 21, 744-749. [CrossRef] [PubMed]

167. Morel, L.; Regan, M.; Higashimori, H.; Ng, S.K.; Esau, C.; Vidensky, S.; Rothstein, J.; Yang, Y. Neuronal exosomal mirna-dependent translational regulation of astroglial glutamate transporter glt1. J. Biol. Chem. 2013, 288, 7105-7116. [CrossRef] [PubMed]

168. Ishtiaq, M.; Campos-Melo, D.; Volkening, K.; Strong, M.J. Analysis of novel nefl mrna targeting micrornas in amyotrophic lateral sclerosis. PLoS ONE 2014, 9, e85653. [CrossRef] [PubMed]

169. Sun, X.; Zhou, Z.; Fink, D.J.; Mata, M. Hspb1 silences translation of pdz-rhogef by enhancing mir-20a and mir-128 expression to promote neurite extension. Mol. Cell. Neurosci. 2013, 57, 111-119. [CrossRef] [PubMed]

170. Kye, M.J.; Niederst, E.D.; Wertz, M.H.; Goncalves Ido, C.; Akten, B.; Dover, K.Z.; Peters, M.; Riessland, M.; Neveu, P.; Wirth, B.; et al. Smn regulates axonal local translation via mir-183/mtor pathway. Hum. Mol. Genet. 2014, 23, 6318-6331. [CrossRef]

171. Ma, G.; Wang, Y.; Li, Y.; Cui, L.; Zhao, Y.; Zhao, B.; Li, K. Mir-206, a key modulator of skeletal muscle development and disease. Int. J. Biol. Sci. 2015, 11, 345-352. [CrossRef] [PubMed]

172. De Felice, B.; Annunziata, A.; Fiorentino, G.; Borra, M.; Biffali, E.; Coppola, C.; Cotrufo, R.; Brettschneider, J.; Giordana, M.L.; Dalmay, T.; et al. Mir-338-3p is over-expressed in blood, cfs, serum and spinal cord from sporadic amyotrophic lateral sclerosis patients. Neurogenetics 2014, 15, 243-253. [CrossRef] [PubMed]

173. De Felice, B.; Guida, M.; Guida, M.; Coppola, C.; De Mieri, G.; Cotrufo, R. A mirna signature in leukocytes from sporadic amyotrophic lateral sclerosis. Gene 2012, 508, 35-40. [CrossRef] [PubMed]

174. Kim, J.; Inoue, K.; Ishii, J.; Vanti, W.B.; Voronov, S.V.; Murchison, E.; Hannon, G.; Abeliovich, A. A microrna feedback circuit in midbrain dopamine neurons. Science 2007, 317, 1220-1224. [CrossRef] [PubMed]

175. Lu, X.C.; Zheng, J.Y.; Tang, L.J.; Huang, B.S.; Li, K.; Tao, Y.; Yu, W.; Zhu, R.L.; Li, S.; Li, L.X. Mir-133b promotes neurite outgrowth by targeting rhoa expression. Cell. Physiol. Biochem. 2015, 35, 246-258. [CrossRef] [PubMed]

176. Raheja, R.; Regev, K.; Healy, B.C.; Mazzola, M.A.; Beynon, V.; Von Glehn, F.; Paul, A.; Diaz-Cruz, C.; Gholipour, T.; Glanz, B.I.; et al. Correlating serum micrornas and clinical parameters in amyotrophic lateral sclerosis. Muscle Nerve 2018, 58, 261-269. [CrossRef]

177. Calvo, A.C.; Cibreiro, G.A.; Merino, P.T.; Roy, J.F.; Galiana, A.; Rufian, A.J.; Cano, J.M.; Martin, M.A.; Moreno, L.; Larrode, P.; et al. Collagen xix alpha 1 improves prognosis in amyotrophic lateral sclerosis. Aging Dis. 2019, 10, 278-292. [CrossRef]

178. De Andrade, H.M.; de Albuquerque, M.; Avansini, S.H.; de, S.R.C.; Dogini, D.B.; Nucci, A.; Carvalho, B.; Lopes-Cendes, I.; Franca, M.C., Jr. Micrornas-424 and 206 are potential prognostic markers in spinal onset amyotrophic lateral sclerosis. J. Neurol. Sci. 2016, 368, 19-24. [CrossRef] 
179. Di Pietro, L.; Baranzini, M.; Berardinelli, M.G.; Lattanzi, W.; Monforte, M.; Tasca, G.; Conte, A.; Logroscino, G.; Michetti, F.; Ricci, E.; et al. Potential therapeutic targets for als: Mir206, mir208b and mir499 are modulated during disease progression in the skeletal muscle of patients. Sci. Rep. 2017, 7, 9538. [CrossRef]

180. Bede, P.; Bokde, A.L.; Byrne, S.; Elamin, M.; Fagan, A.J.; Hardiman, O. Spinal cord markers in als: Diagnostic and biomarker considerations. Amyotroph. Lateral Scler. 2012, 13, 407-415. [CrossRef]

181. Kleaveland, B.; Shi, C.Y.; Stefano, J.; Bartel, D.P. A network of noncoding regulatory rnas acts in the mammalian brain. Cell 2018, 174, 350-362 e317. [CrossRef] [PubMed]

182. Van Damme, P.; Dewil, M.; Robberecht, W.; Van Den Bosch, L. Excitotoxicity and amyotrophic lateral sclerosis. Neurodegener. Dis. 2005, 2, 147-159. [PubMed]

183. King, A.E.; Woodhouse, A.; Kirkcaldie, M.T.; Vickers, J.C. Excitotoxicity in als: Overstimulation, or overreaction? Exp. Neurol. 2016, 275, 162-171. [CrossRef] [PubMed]

184. Plaitakis, A.; Constantakakis, E.; Smith, J. The neuroexcitotoxic amino acids glutamate and aspartate are altered in the spinal cord and brain in amyotrophic lateral sclerosis. Ann. Neurol. 1988, 24, 446-449. [CrossRef] [PubMed]

185. Rothstein, J.D.; Tsai, G.; Kuncl, R.W.; Clawson, L.; Cornblath, D.R.; Drachman, D.B.; Pestronk, A.; Stauch, B.L.; Coyle, J.T. Abnormal excitatory amino acid metabolism in amyotrophic lateral sclerosis. Ann. Neurol. 1990, 28, 18-25. [CrossRef] [PubMed]

186. Shaw, P.J.; Forrest, V.; Ince, P.G.; Richardson, J.P.; Wastell, H.J. Csf and plasma amino acid levels in motor neuron disease: Elevation of csf glutamate in a subset of patients. Neurodegeneration 1995, 4, $209-216$. [CrossRef] [PubMed]

187. Spreux-Varoquaux, O.; Bensimon, G.; Lacomblez, L.; Salachas, F.; Pradat, P.F.; Le Forestier, N.; Marouan, A.; Dib, M.; Meininger, V. Glutamate levels in cerebrospinal fluid in amyotrophic lateral sclerosis: A reappraisal using a new hplc method with coulometric detection in a large cohort of patients. J. Neurol. Sci. 2002, 193, 73-78. [CrossRef]

188. Ferrarese, C.; Sala, G.; Riva, R.; Begni, B.; Zoia, C.; Tremolizzo, L.; Galimberti, G.; Millul, A.; Bastone, A.; Mennini, T.; et al. Decreased platelet glutamate uptake in patients with amyotrophic lateral sclerosis. Neurology 2001, 56, 270-272. [CrossRef]

189. Kumar, A.; Bala, L.; Kalita, J.; Misra, U.K.; Singh, R.L.; Khetrapal, C.L.; Babu, G.N. Metabolomic analysis of serum by (1) h nmr spectroscopy in amyotrophic lateral sclerosis. Clin. Chim. Acta 2010, 411, 563-567. [CrossRef]

190. Andreadou, E.; Kapaki, E.; Kokotis, P.; Paraskevas, G.P.; Katsaros, N.; Libitaki, G.; Zis, V.; Sfagos, C.; Vassilopoulos, D. Plasma glutamate and glycine levels in patients with amyotrophic lateral sclerosis: The effect of riluzole treatment. Clin. Neurol. Neurosurg. 2008, 110, 222-226. [CrossRef]

191. Tarasiuk, J.; Kułakowska, A.; Drozdowski, W.; Kornhuber, J.; Lewczuk, P. Csf markers in amyotrophic lateral sclerosis. J. Neural Transm. (Vienna) 2012, 119, 747-757. [CrossRef] [PubMed]

192. Meng, X.E.; Li, N.; Guo, D.Z.; Pan, S.Y.; Li, H.; Yang, C. High plasma glutamate levels are associated with poor functional outcome in acute ischemic stroke. Cell. Mol. Neurobiol. 2015, 35, 159-165. [CrossRef] [PubMed]

193. Rajda, C.; Pukoli, D.; Bende, Z.; Majlath, Z.; Vecsei, L. Excitotoxins, mitochondrial and redox disturbances in multiple sclerosis. Int. J. Mol. Sci. 2017, 18, 353. [CrossRef] [PubMed]

194. Rothstein, J.D.; Martin, L.J.; Kuncl, R.W. Decreased glutamate transport by the brain and spinal cord in amyotrophic lateral sclerosis. N. Engl. J. Med. 1992, 326, 1464-1468. [CrossRef]

195. Rothstein, J.D.; Van Kammen, M.; Levey, A.I.; Martin, L.J.; Kuncl, R.W. Selective loss of glial glutamate transporter glt-1 in amyotrophic lateral sclerosis. Ann. Neurol. 1995, 38, 73-84. [CrossRef] [PubMed]

196. Lin, C.L.; Bristol, L.A.; Jin, L.; Dykes-Hoberg, M.; Crawford, T.; Clawson, L.; Rothstein, J.D. Aberrant rna processing in a neurodegenerative disease: The cause for absent eaat2, a glutamate transporter, in amyotrophic lateral sclerosis. Neuron 1998, 20, 589-602. [CrossRef]

197. Flomen, R.; Makoff, A. Increased rna editing in eaat2 pre-mrna from amyotrophic lateral sclerosis patients: Involvement of a cryptic polyadenylation site. Neurosci. Lett. 2011, 497, 139-143. [CrossRef] [PubMed]

198. Rothstein, J.D.; Jin, L.; Dykes-Hoberg, M.; Kuncl, R.W. Chronic inhibition of glutamate uptake produces a model of slow neurotoxicity. Proc. Natl. Acad. Sci. USA 1993, 90, 6591-6595. [CrossRef]

199. Velasco, I.; Tapia, R.; Massieu, L. Inhibition of glutamate uptake induces progressive accumulation of extracellular glutamate and neuronal damage in rat cortical cultures. J. Neurosci. Res. 1996, 44, 551-561. [CrossRef] 
200. Tanaka, K.; Watase, K.; Manabe, T.; Yamada, K.; Watanabe, M.; Takahashi, K.; Iwama, H.; Nishikawa, T.; Ichihara, N.; Kikuchi, T.; et al. Epilepsy and exacerbation of brain injury in mice lacking the glutamate transporter glt-1. Science 1997, 276, 1699-1702. [CrossRef]

201. Corona, J.C.; Tapia, R. Ampa receptor activation, but not the accumulation of endogenous extracellular glutamate, induces paralysis and motor neuron death in rat spinal cord in vivo. J. Neurochem. 2004, 89, 988-997. [CrossRef] [PubMed]

202. Tovar, Y.R.L.B.; Santa-Cruz, L.D.; Zepeda, A.; Tapia, R. Chronic elevation of extracellular glutamate due to transport blockade is innocuous for spinal motoneurons in vivo. Neurochem. Int. 2009, 54, 186-191. [CrossRef] [PubMed]

203. Beart, P.M.; O'Shea, R.D. Transporters for l-glutamate: An update on their molecular pharmacology and pathological involvement. Br. J. Pharmacol. 2009, 150, 5-17. [CrossRef] [PubMed]

204. Meyer, T.; Fromm, A.; Münch, C.; Schwalenstöcker, B.; Fray, A.E.; Ince, P.G.; Stamm, S.; Grön, G.; Ludolph, A.C.; Shaw, P.J. The rna of the glutamate transporter eaat2 is variably spliced in amyotrophic lateral sclerosis and normal individuals. J. Neurol. Sci. 1999, 170, 45-50. [CrossRef]

205. Ferrarese, C.; Begni, B.; Canevari, C.; Zoia, C.; Piolti, R.; Frigo, M.; Appollonio, I.; Frattola, L. Glutamate uptake is decreased in platelets from alzheimer's disease patients. Ann. Neurol. 2000, 47, 641-643. [CrossRef]

206. Ferrarese, C.; Tremolizzo, L.; Rigoldi, M.; Sala, G.; Begni, B.; Brighina, L.; Ricci, G.; Albizzati, M.G.; Piolti, R.; Crosti, F; et al. Decreased platelet glutamate uptake and genetic risk factors in patients with parkinson's disease. Neurol. Sci. 2001, 22, 65-66. [CrossRef] [PubMed]

207. Bos, I.W.; Hoogland, G.; Meine Jansen, C.F.; Willigen, G.; Spierenburg, H.A.; van den Berg, L.H.; de Graan, P.N. Increased glutamine synthetase but normal eaat2 expression in platelets of als patients. Neurochem. Int. 2006, 48, 306-311. [CrossRef]

208. Heath, P.R.; Shaw, P.J. Update on the glutamatergic neurotransmitter system and the role of excitotoxicity in amyotrophic lateral sclerosis. Muscle Nerve 2002, 26, 438-458. [CrossRef]

209. Carriedo, S.G.; Yin, H.Z.; Weiss, J.H. Motor neurons are selectively vulnerable to ampa/kainate receptor-mediated injury in vitro. J. Neurosci. 1996, 16, 4069-4079. [CrossRef]

210. Van Den Bosch, L.; Van Damme, P.; Bogaert, E.; Robberecht, W. The role of excitotoxicity in the pathogenesis of amyotrophic lateral sclerosis. Biochim. Biophys. Acta 2006, 1762, 1068-1082. [CrossRef]

211. Burnashev, N.; Monyer, H.; Seeburg, P.H.; Sakmann, B. Divalent ion permeability of ampa receptor channels is dominated by the edited form of a single subunit. Neuron 1992, 8, 189-198. [CrossRef]

212. Melcher, T.; Maas, S.; Herb, A.; Sprengel, R.; Seeburg, P.H.; Higuchi, M. A mammalian rna editing enzyme. Nature 1996, 379, 460-464. [CrossRef] [PubMed]

213. Nishikura, K. Functions and regulation of rna editing by adar deaminases. Annu. Rev. Biochem. 2010, 79, 321-349. [CrossRef] [PubMed]

214. Feldmeyer, D.; Kask, K.; Brusa, R.; Kornau, H.C.; Kolhekar, R.; Rozov, A.; Burnashev, N.; Jensen, V.; Hvalby, O.; Sprengel, R.; et al. Neurological dysfunctions in mice expressing different levels of the $\mathrm{q} / \mathrm{r}$ site-unedited ampar subunit glur-b. Nat. Neurosci. 1999, 2, 57-64. [CrossRef]

215. Higuchi, M.; Maas, S.; Single, F.N.; Hartner, J.; Rozov, A.; Burnashev, N.; Feldmeyer, D.; Sprengel, R.; Seeburg, P.H. Point mutation in an ampa receptor gene rescues lethality in mice deficient in the rna-editing enzyme adar2. Nature 2000, 406, 78-81. [CrossRef]

216. Seeburg, P.H. A-to-i editing: New and old sites, functions and speculations. Neuron 2002, 35, 17-20. [CrossRef]

217. Kawahara, Y.; Ito, K.; Sun, H.; Aizawa, H.; Kanazawa, I.; Kwak, S. Glutamate receptors: Rna editing and death of motor neurons. Nature 2004, 427, 801. [CrossRef]

218. Hideyama, T.; Yamashita, T.; Aizawa, H.; Tsuji, S.; Kakita, A.; Takahashi, H.; Kwak, S. Profound downregulation of the rna editing enzyme adar2 in als spinal motor neurons. Neurobiol. Dis. 2012, 45, 1121-1128. [CrossRef]

219. Kawahara, Y.; Sun, H.; Ito, K.; Hideyama, T.; Aoki, M.; Sobue, G.; Tsuji, S.; Kwak, S. Underediting of glur2 mrna, a neuronal death inducing molecular change in sporadic als, does not occur in motor neurons in als1 or sbma. Neurosci. Res. 2006, 54, 11-14. [CrossRef]

220. Aizawa, H.; Sawada, J.; Hideyama, T.; Yamashita, T.; Katayama, T.; Hasebe, N.; Kimura, T.; Yahara, O.; Kwak, S. Tdp-43 pathology in sporadic als occurs in motor neurons lacking the rna editing enzyme adar2. Acta Neuropathol. 2010, 120, 75-84. [CrossRef] 
221. Yamashita, T.; Hideyama, T.; Hachiga, K.; Teramoto, S.; Takano, J.; Iwata, N.; Saido, T.C.; Kwak, S. A role for calpain-dependent cleavage of tdp-43 in amyotrophic lateral sclerosis pathology. Nat. Commun. 2012, 3, 1307. [CrossRef] [PubMed]

222. Hosaka, T.; Yamashita, T.; Teramoto, S.; Hirose, N.; Tamaoka, A.; Kwak, S. Adar2-dependent a-to-i rna editing in the extracellular linear and circular rnas. Neurosci. Res. 2018. [CrossRef] [PubMed]

223. Aizawa, H.; Hideyama, T.; Yamashita, T.; Kimura, T.; Suzuki, N.; Aoki, M.; Kwak, S. Deficient rna-editing enzyme adar2 in an amyotrophic lateral sclerosis patient with a fus(p5251) mutation. J. Clin. Neurosci. 2016, 32, 128-129. [CrossRef] [PubMed]

224. Selvaraj, B.T.; Livesey, M.R.; Zhao, C.; Gregory, J.M.; James, O.T.; Cleary, E.M.; Chouhan, A.K.; Gane, A.B.; Perkins, E.M.; Dando, O.; et al. C9orf72 repeat expansion causes vulnerability of motor neurons to ca(2+)-permeable ampa receptor-mediated excitotoxicity. Nat. Commun. 2018, 9, 347. [CrossRef] [PubMed]

225. Moore, S.; Alsop, E.; Lorenzini, I.; Starr, A.; Rabichow, B.E.; Mendez, E.; Levy, J.L.; Burciu, C.; Reiman, R.; Chew, J.; et al. Adar2 mislocalization and widespread rna editing aberrations in c9orf72-mediated als/ftd. Acta Neuropathol. 2019, 138, 49-65. [CrossRef] [PubMed]

226. Yamashita, T.; Chai, H.L.; Teramoto, S.; Tsuji, S.; Shimazaki, K.; Muramatsu, S.; Kwak, S. Rescue of amyotrophic lateral sclerosis phenotype in a mouse model by intravenous aav9-adar2 delivery to motor neurons. EMBO Mol. Med. 2013, 5, 1710-1719. [CrossRef] [PubMed]

227. Akamatsu, M.; Yamashita, T.; Hirose, N.; Teramoto, S.; Kwak, S. The ampa receptor antagonist perampanel robustly rescues amyotrophic lateral sclerosis (als) pathology in sporadic als model mice. Sci. Rep. 2016, 6, 28649. [CrossRef]

(C) 2019 by the authors. Licensee MDPI, Basel, Switzerland. This article is an open access article distributed under the terms and conditions of the Creative Commons Attribution (CC BY) license (http://creativecommons.org/licenses/by/4.0/). 